\title{
JNK3 overexpression in the entorhinal cortex disseminates to the hippocampus and induces cognitive deficiencies and Tau misfolding
}

\section{Carlos G. Ardanaz}

University of Navarra: Universidad de Navarra

\section{Arantza Bejarano}

Universidad de Navarra

\section{Beatriz Echarte}

Universidad de Navarra

\section{Cristian Smerdou}

CIMA: Centro de Investigacion Medica Aplicada

\section{Eva Martisova}

CIMA: Centro de Investigacion Medica Aplicada

Iván Martínez-Valbuena

CIMA: Centro de Investigacion Medica Aplicada

\section{María R. Luquin}

University of Navarra Clinic: Clinica Universidad de Navarra

María J. Ramírez

Universidad de Navarra

Maite Solas ( $\square$ msolaszu@unav.es)

University of Navarra: Universidad de Navarra https://orcid.org/0000-0001-7670-3237

\section{Research Article}

Keywords: JNK3, Entorhinal Cortex, Cognitive Impairment, Tau, Neuroinflammation, Gliosis

Posted Date: March 28th, 2022

DOI: https://doi.org/10.21203/rs.3.rs-1381483/v2

License: (c) (i) This work is licensed under a Creative Commons Attribution 4.0 International License. Read Full License 


\section{Abstract}

C-Jun N-terminal kinases (JNKs) are a family of protein kinases that can be activated by numerous stimuli and regulate a broad spectrum of biological processes in the Central Nervous System. JNK3, a specific isoform in the brain, have been shown to be involved in neurodegenerative conditions. Even though JNK over-activation has been observed in human brains affected with Alzheimer's disease (AD), its role in $A D$ pathology development is still unclear.

One of the early regions of neuronal volume loss in $A D$ is the Entorhinal Cortex (EC). Indeed, the loss of projections from $E C$ to hippocampus $(\mathrm{Hp})$ in the early phases of $A D$ has raised the idea that the connection between EC and Hp could be deteriorated in AD. Thus, the main aim of the current work is to address if JNK3 overexpression in the EC could spread to the hippocampus, leading to cognitive deficiencies, similar to what occurs in early stages of AD.

Data acquired in the current study suggest that JNK3 overexpression in the EC is also observed in the Hp and this leads to cognitive impairment. Moreover, pro-inflammatory cytokines expression and Tau immunoreactivity appeared to be increased both in the EC and Hp. Therefore, activation of inflammatory signaling and induction of Tau aberrant misfolding caused by JNK3 could be the underlying mechanism of the observed cognitive impairment. Altogether, JNK3 overexpression may disseminate from EC to Hp inducing cognitive dysfunction in vulnerable brain regions and may underlie the alterations observed in early stages of $A D$.

\section{Introduction}

Cells constantly interact with their environment by receiving and sending signals. These cues that the cell receives control many functional aspects by activating different signaling pathways, such as the mitogen-activated kinases called MAPK (Mitogen-Activated Protein Kinases) that are subdivided into three families: p38, ERK and c-Jun N-terminal kinases (JNK) [1, 2].

The JNK family proteins can be activated by numerous stimuli. When activated, they in turn modify the activity of other proteins by adding phosphate groups [3]. In this way JNK regulates important functions in a broad spectrum of biological processes in the cytoplasm, mitochondria and also in the nucleus, especially in the central nervous system (CNS) [1].

JNK kinase is encoded by three genes, namely Jnk1 (also known as Mapk8), Jnk2 (Mapk9) and Jnk3 (Mapk10) [4, 5], but due to the alternative splicing, ten different splice variants can be generated [1, 6, 7]. The ten different variants are grouped depending on the homologous protein regions in the three known isoforms of JNK: JNK1, JNK2 and JNK3. Albeit JNK1 and JNK2 are widely distributed throughout the different tissues, JNK3 principally is found in the CNS [8].

JNK3 is responsible of regulating the functions of the brain in both healthy and pathological conditions. JNK3 is involved in brain maturing [9], neurite creation and flexibility [10,11], and it is implicated in 
memory capacity and learning $[12,13]$. In pathological circumstances, JNK3 has been proposed as a deletereous transducer signal, and it seems to be over-stimulated in the adult brain after pernicious stress-stimuli, like hypoxia, ischemia or epilepsies $[8,14-18]$.

Neuroinflammation is a defense mechanism of the brain, initiated in the CNS by the immune system to protect it from infections and other threats. However, when it becomes chronic, it produces metabolic changes that lead to tissue and cognitive degeneration potentially resulting in pathologies such as Parkinson's disease (PD), Alzheimer's disease (AD) and others $[19,20]$. It has been reported that the total amount of nuclear JNK is rapidly and transiently increased after neuroinflammatory stimulus, leading to augmented levels of inducible NO synthase (iNOS) and pro-inflammatory mediators such as interleukins [21-23]. These findings indicate that JNK plays crucial roles in the neuroinflammatory processes underlying various neurodegenerative disorders.

$A D$ is a progressive CNS degenerative disease characterized by neurofibrillary tangles [24] and amyloid- $\beta$ $(A B)$ deposits [25]. It has been shown that post-mortem brains of patients with this disease exhibit anomalously elevated concentrations of JNK activity [26-28] and preclinical research using animal models evinces that JNK can have a significant impact on AD pathology increasing A $\beta$ plaque load [28, 29] and Tau hyperphosphorylation [17, 30]. JNK activity is enhanced in AD mouse models that carry the Swedish mutant variant of amyloid precursor protein (APP) and/or harbor a mutated presenilin 1 (engaged in APP cleavage) [28, 31, 32]. Application of JNK inhibitors to brain slices of AD mouse models (Tg2576/PS1P264L) in vitro decreases degeneration of pyramidal neurons [33] and chronic administration of a JNK inhibitor peptide to TgCRND8 mice (with multiple mutations in APP) restores memory impairment and LTP abnormalities [34]. Furthermore, genetic deletion of Jnk3 in familial AD mice decreases $A \beta$ plaque load [28].

Aside from glycogen synthase kinase 3 (GSK3), p38 and ERK, Tau could be phosphorylated by JNK on various locations that are hyperphosphorylated in paired helical fragments [30,35]. Patients with AD have shown incremented activity of JNK in neurofibrillary tangles in brain tissue [36]. In addition, JNK activity is enhanced in tangles in Tg2576/PS1P264L and traumatic brain injury mouse models, where JNK is colocalized with phosphorylated Tau [31, 32]. Of note, a peptide inhibitor of JNK, D-JNKI-1, reduces Tau phosphorylation and aggregation [32].

One of the first regions undergoing neuronal cell loss in $A D$ cases is the Entorhinal Cortex (EC) [37, 38]. In both primates and rodents, the EC is located in the temporal lobe and nearby the hippocampus (Hp). Two major divisions can be distinguished: the medial EC (MEC) and the lateral EC (LEC). The EC innervates the $\mathrm{Hp}$ through the perforant pathway projection. Indeed, in early phases of $A D$ the loss of the projection from EC to Hp has led to the idea that the connection between EC and Hp could be deteriorated in AD [38, 39], leading to cognitive deficiencies.

Taking into account the relationship between JNK3, neuroinflammation, hiperphosphorylation of tau and $A D$, the present work aims to explore whether an overexpression of JNK3 in the EC could spread to the hippocampus, leading to a cognitive deficiency, similar to that observed in early phases of AD. 


\section{Material And Methods \\ 2.1. Animals}

In this study, 12 weeks old ICR mice were used (Envigo, Huntingdon, UK). Animals were housed in a temperature $\left(21 \pm 1^{\circ} \mathrm{C}\right)$ and humidity $(55 \pm 1 \%)$ controlled room on a $12 \mathrm{~h}$ light/dark cycle, with ad libitum access to a standard chow diet and water. Experimental procedures were conducted in accordance with the European and Spanish regulations (2003/65/EC; 1201/2005) for the care and use of laboratory animals and approved by the Ethical Committee of University of Navarra (ethical protocol number 038 17).

\subsection{Cells}

BHK-21 cells (ATCC: CCL-10) and derived stable cell lines were cultured in BHK-21 Glasgow MEM (Gibco BRL, UK) supplemented with $5 \% \mathrm{FCS}, 10 \%$ tryptose phosphate broth, 2 mM glutamine, 20 mM HEPES, $100 \mu \mathrm{g} / \mathrm{ml}$ streptomycin and $100 \mathrm{lU} / \mathrm{ml}$ penicillin (BHK complete medium). HuH-7 (Japanese Collection of Research Bioresources Cell Bank: 0403) and HEK-293T (ATCC $\AA$ CRL-3216 ${ }^{\text {TM }}$ ) cells were grown in DMEM (Gibco BRL) supplemented with 10\% FBS, $2 \mathrm{mM}$ glutamine, and $100 \mu \mathrm{g} / \mathrm{mL}$ streptomycin and $100 \mathrm{U} / \mathrm{mL}$ penicillin.

\subsection{Plasmid}

A synthetic gene containing the coding sequences of mouse JNK3 isoform (NCBI Reference Sequence: NP_001075036.1) and green fluorescent protein (GFP) linked by the IRES (internal ribosome binding site) sequence of the encephalomyocarditis virus was generated. The IRES sequence allows JNK3 and GFP to be translated from the same mRNA, which allows us to identify cells that express recombinant JNK3 in vivo. The synthesis of this gene was entrusted to the company GenScript (Piscataway, USA). The synthetic cassette was subcloned into the pAAV-CAG-GFP plasmid (Pignataro et al., 2017), substituting the GFP gene. In this way, the plasmid pAAV-CAG-JNK3-GFP was generated in which the JNK3-IRES-GFP sequence is under the transcriptional control of the constitutive CAG promoter. This promoter has been shown to be highly effective for expression in neurons [40].

\subsection{Viral Vector Production}

Recombinant single-stranded AAV8 vectors were purified from HEK-293T cells that had been cotransfected using linear polyethylenimine $25 \mathrm{kDa}$ (Polysciences, Warrington, PA, USA) with two different plasmids: a plasmid containing ITR-flanked transgene constructs (pAAV-CAG-JNK3-GFP) and a plasmid containing the adenoviral helper genes AAV8 cap (named pDP8.ape, Plasmid Factory, Bielefeld, Germany). Seventy-two hours post-transfection the supernatant was collected and treated with polyethylene glycol solution (PEG8000, $8 \% \mathrm{v} / \mathrm{v}$ final concentration) for $48-72 \mathrm{~h}$ at $4{ }^{\circ} \mathrm{C}$. Supernatant was then centrifuged at $1500 \mathrm{~g}$ for $15 \mathrm{~min}$. Cells containing AAV particles were collected and treated with lysis buffer (50 mM Tris-Cl, $150 \mathrm{mM} \mathrm{NaCl}, 2 \mathrm{mM} \mathrm{MgCl}_{2}, 0.1 \%$ Triton X-100) and kept at $-80^{\circ} \mathrm{C}$. Three cycles of freezing and thawing were applied to both supernatant and cell lysate. Viral particles obtained from cell 
supernatant and lysate were purified by ultracentrifugation at $350,000 \mathrm{~g}$ for $2.5 \mathrm{~h}$ in a $15-57 \%$ in an iodixanol gradient according to the method of Zolotukhin et al. (1999). The viral batches were then concentrated further by passage through Amicon Ultra Centrifugal Filters-Ultracel $100 \mathrm{~K}$ (Millipore, Burlington, MA, USA) All vector stocks were kept at $-80^{\circ} \mathrm{C}$ until used.

AAV vector titers (viral particles $(\mathrm{vp}) / \mathrm{ml}$ ) were determined by quantitative PCR for viral genome copies extracted from DNAase-treated viral particles (High Pure Viral Nucleic Acid Kit, Roche). The primers used in the q-PCR were Forward-eGFP: 5'-GTCCGCCCTGAGCAAACA-3' and Reverse-eGFP: 5' TCCAGCAGGACCATGTGATC-3'. Vector titers obtained was $>10^{12}$ viral genomes (VG)/ml.

\subsection{Analysis of JNK3 expression in vitro}

BHK and HuH-7 cells were transfected with 2, 4 and $6 \mu \mathrm{g}$ of pAAV-CAG-JNK3-GFP plasmids using lipofectamine 2000 (Thermo Fisher). Cells were fixed at $24 \mathrm{~h}$ and pJNK and total JNK expression was detected by immunoblotting and immunofluorescence using a primary mouse monoclonal antibody specific for anti-pJNK (1:1000, Cell Signalling Technology, Beverly, MA, USA), anti-totalJNK (1:1000, Cell Signalling Technology, Beverly, MA, USA). A donkey anti-rabbit Alexa-546-conjugated antiserum (Invitrogen ref. A21202, 1:1000) was used for detection.

\subsection{Intraentorhinal injection}

Intraentrorhinal injection of JNK3-AAV $\left(1 \times 10^{10} \mathrm{vp}\right)$ was stereotaxically performed in both lateral (LEC) (1 $\mu \mathrm{L})$ and medial $(\mathrm{MEC})(0.5 \mu \mathrm{L})$ entorhinal cortex $(n=14)$. The coordinates for targeting the LEC were anterior-posterior, -4.1 ; medial-lateral, $+/-4.3$; dorso-ventral, -4.9 from bregma [41]. Coordinates for the MEC were anterior-posterior, -4.1 ; medial-lateral, +/- 3.5; dorso-ventral, -5.1 from bregma [41]. Sham animals $(n=12)$ received equivalent amounts of sterile phosphate buffer saline. Mice were sacrificed 3 months after the injection.

\subsection{Behavioral Tests \\ 2.7.1. Open Field Test}

Locomotor activity was measured for $30 \mathrm{~min}$ in an open field $(35 \times 35 \mathrm{~cm}, 45 \mathrm{~cm}$ height) made of black wood, using a video-tracking system (Ethovision 11.5, Noldus Information Technology B.V., The Netherlands), in a dimly illuminated room. Total path distance $(\mathrm{cm})$ was analyzed.

\subsubsection{Novel Object Recognition Task (NORT)}

The open field consisted of a square divided into four sections ( $35 \mathrm{~cm} \times 35 \mathrm{~cm} \times 45 \mathrm{~cm}$ each) with black walls. On the previous day to the experiment, animals were familiarized with the square for $30 \mathrm{~min}$. During the first trial (sample phase), two identical objects were placed inside the cubicle, and the mice were allowed to freely explore for $5 \mathrm{~min}$. For the second task, which took place $1 \mathrm{~h}$ later, one object was replaced by another and the exploration time was recorded for $5 \mathrm{~min}$. Results were expressed as percentage of time spent exploring the new object with respect to the total exploration time 
(discrimination index). This behavioral test was carried out using a video-tracking system (Ethovision 11.5; Noldus Information Technology B.V, Wageningen, Netherlands).

\subsubsection{Morris Water Maze (MWM)}

The MWM, a hippocampus-dependent learning task, was used to test spatial memory and to evaluate the working and reference memory. The water maze was a circular pool (diameter of $145 \mathrm{~cm}$ ) filled with water $\left(21-22^{\circ} \mathrm{C}\right)$ and virtually divided into four equal quadrants identified as northeast, northwest, southeast, and southwest.

Hidden-platform training was conducted with the platform placed in the northeast quadrant $1 \mathrm{~cm}$ below the water surface over 9 consecutive days (4 trials/day). Several large visual cues were placed in the room to guide the mice to the hidden platform. Each trial was finished when the mouse reached the platform (escape latency) or after $60 \mathrm{~s}$, whichever came first. Mice failing to reach the platform were guided onto it. After each trial mice remained on the platform for $15 \mathrm{~s}$. To test memory, probe trials were performed at the 4th, 7th and last day of the test (10th day). In the probe trials the platform was removed from the pool and mice were allowed to swim for $60 \mathrm{~s}$. The percent of time spent in the target quadrant was recorded. All trials were monitored by a video camera set above the center of the pool and connected to a video tracking system (Ethovision 3.0; Noldus Information Technology B.V, Wageningen, Netherlands).

\subsection{Biochemical Measurements 2.8.1. Tissue collection}

Mice were euthanized by decapitation. Brains were immediately extracted and dissected on ice to obtain the EC and the hippocampus, and stored at $-80^{\circ} \mathrm{C}$.

For immunohistochemistry assays, right hemispheres from 5 mice per group were fixed by immersion in $4 \%$ paraformaldehyde in $0.1 \mathrm{M}$ PBS ( $\mathrm{pH} 7.4$ ) for $24 \mathrm{~h}$ followed by $30 \%$ sucrose solution. Brains were cut into series of $40 \mu \mathrm{m}$ slices.

\subsubsection{Immunofluorescence (IF)}

For immunofluorescence, free-floating brain sections were washed (3×10 min) with PBS 0.1 M (pH 7.4) and incubated in blocking solution (PBS containing 0.3\% Triton X-100, 0.1\% BSA and 2\% normal donkey serum) for $2 \mathrm{~h}$ at room temperature. Primary and secondary antibodies were diluted in the blocking solution. Sections were incubated with the primary antibody overnight at $4^{\circ} \mathrm{C}$, washed with PBS and incubated with the secondary antibody for $2 \mathrm{~h}$ at room temperature, protected from light. The primary antibodies used were anti-GFP (1:1000, Invitrogen, Carlsbad, California, USA), anti-GFAP (1:1000, Cell Signalling Technology, Beverly, MA, USA) and anti-lba1 (1:1000, Wako, Wako, Osaka, Japan). Secondary antibody used was Alexa Fluor 546 goat anti-mouse for GFAP and Alexa Fluor 488 goat anti-rabbit for GFP and Iba1 (1:400, Invitrogen-Molecular Probes, Eugene, OR, USA). To ensure comparable 
immunostaining, sections were processed together under identical conditions. Fluorescence signals were detected with confocal microscope LSM 510 Meta (Carl Zeiss, Oberkochen, Germany).

\subsubsection{Immunohistrochemistry}

Immunohistochemical examination of brains was performed using mouse monoclonal antibodies against Tau MC1 epitope (1:100, donated by Peter Davies, Department of Pathology, Albert Einstein College of Medicine), Tau ALZ50 epitope (1:100, donated by Peter Davies, Department of Pathology, Albert Einstein College of Medicine), Asp421 cleaved Tau clone C3 (1:250, Merck, Darmstadt, Germany) and Ser422 phospho-Tau (1:250, ThermoFisher, Waltham, Massachusetts, USA). Antibody binding was detected with a biotinylated secondary antibody and the antibodies were visualized using an avidinbiotin-peroxidase complex with 3,3'-diaminobenzidine tetrahydrochloride (DAB) as the chromogen.

\subsubsection{Quantitative Reverse Transcription Polymerase Chain Reaction (qRT-PCR)}

For qRT-PCR analysis total RNA was extracted from respective tissues using Trizol reagent. Isolated total RNA was reverse-transcribed into cDNA using commercially available kits (Applied Biosystems). All subsequent qRT-PCR reactions were performed on a QuantStudio 7 Flex Real-Time PCR System (Applied Biosystems). For normalization threshold cycles (Ct-values) of all replicate analyses were normalized to Gapdh within each sample to obtain sample-specific $\Delta \mathrm{Ct}$ values (= Ct gene of interest - Ct Gapdh). The following Taqman probes (Applied Biosystems) were used: MAPK10 (Mm00436518_m1), TNFa (Mm00443258_m1), IL-1及 (Mm00434228_m1) and IL-6 (Mm00446190_m1).

\subsubsection{Western Blotting (WB)}

Total protein homogenates were obtained by homogenizing the dissected EC or Hp in ice-cold lysis buffer ( $\mathrm{NaCl}$ 200mM, HEPES 100mM, Glycerol 10\%, NaF 200mM, Na ${ }_{4} \mathrm{P}_{2} \mathrm{O}_{7} 2 \mathrm{mM}$, EDTA 5mM, EGTA $1 \mathrm{mM}$, DTT 2mM, PMSF 0.5mM, Orthovanadate $1 \mathrm{mM}$ and NP-40, Inhibitors of Proteases and Inhibitors of Phosphatases at 1\%) and centrifuged at $13000 \mathrm{rpm} 4^{\circ} \mathrm{C}$ for $20 \mathrm{~min}$. The supernatant was aliquoted and frozen at $-80^{\circ} \mathrm{C}$ until use. Homogenates (30 $\mu \mathrm{g}$ of protein) were separated by electrophoresis on polyacrylamide gels (7.5\%). Membranes were probed overnight at $4^{\circ} \mathrm{C}$ with the following primary antibodies: anti-GFAP (1:1000, Cell Signalling Technology, Beverly, MA, USA), anti-CD11b (1:1000, NB11089474, Minneapolis, MN, USA), anti-pJNK (1:1000, Cell Signalling Technology, Beverly, MA, USA), antitotalJNK (1:1000, Cell Signalling Technology, Beverly, MA, USA), Tau MC1 epitope (1:1000, donated by Peter Davies, Department of Pathology, Albert Einstein College of Medicine), Tau ALZ50 epitope (1:1000, donated by Peter Davies, Department of Pathology, Albert Einstein College of Medicine), Asp421 cleaved Tau clone C3 (1:1000, Merck, Darmstadt, Germany) and Ser422 phospho-Tau (1:1000, ThermoFisher, Waltham, Massachusetts, USA). Secondary antibodies conjugated to IRDye 800CW or IRDye 680CW (LICOR Biosciences, Lincoln, NE) were diluted to 1:5000 in TBS with 5\% BSA. Bands were visualized using Odyssey Infrared Imaging System (LI-COR Biosciences, Lincoln, NE). Optical density (OD) was quantified for each band using Image Studio Lite software and normalized with $\beta$-actin (mouse monoclonal, 1:10000, Sigma-Aldrich) that was used as an internal control. 


\subsection{Statistical Analysis}

Results, reported as means \pm SEM, were analyzed by Graph Pad Prism 6.0 and normality was checked by Shapiro-Wilk's test $(p<0.05)$. In the acquisition phase of the MWM, over-all treatment effects were examined by two-way repeated measures ANOVA (treatment $x$ trial). Differences between trials within groups were analyzed using a factorial ANOVA with replicates. Data in the retention phase and neurochemical data were analyzed with Student's $t$ test. In all cases, the significance level was set at $p<$ 0.05 .

\section{Results}

\subsection{Analysis of AAV transduction efficacy}

After demonstrating a successful JNK3 expression in vitro (Suppl Fig. 1), a dose of $1 \times 10^{10}$ VG of AAV8JNK3-GFP vector (AAV-JNK3 group) or PBS (Sham group) was injected bilaterally into medial and lateral EC by stereotactic injection in vivo. Mice did not display any adverse reaction or behavioral changes after the intracranial surgery or during the subsequent period until sacrifice. Three months after vector injection, mice were euthanized and GFP expression was analyzed. GFP expression was detected in the targeted area of all AAV-JNK3 treated mice, but no fluorescence was observed in the Sham group (Fig. 1a). Neurons in the EC interact extensively with hippocampal neurons, a key brain area that features pathological signs and abundant amyloid plaques in AD. Interestingly, we found that some hippocampal areas of AAV-JNK3 treated mice, which seem to correspond with the molecular layer of the dentate gyrus, expressed GFP (Fig. 1a). A closer analysis of these areas revealed that while somatic-like fluorescent shapes are observed in the injection site at the EC (Fig. 1b, medial EC and lateral EC panels), however fiber-like fluorescent shapes are observed in the $\mathrm{Hp}$ (Fig. 1b, Hp panel), which could indicate that the AAV delivered into the EC reaches the Hp through EC axonal projections (Fig. 1b, EC-Hp panel).

To further verify the viral expression of GFP and JNK3 in the EC and Hp of the AAV-injected mice, qRTPCRs were performed three months after the injections and compared to similar qRT-PCRs conducted with Sham-injected mice tissue. Our data showed a significant increase of GFP not only in the EC but also in Hp (Fig. 1C). In a similar way, JNK3 expression was markedly increased in the EC and the Hp in the AAV injected group (Fig. 1d).

Western blot analysis of EC and Hp protein extracts obtained from Sham- or AAV-injected mice euthanized three months after injection revealed that entorhinal AAV-JNK3 administration resulted in a marked accumulation of JNK protein compared to Sham-injected animals not only in the injection site, i.e. EC (Fig. 1e), but also in the Hp (Fig. 1f) and that this accumulation was still present after 3 months.

\subsection{Behavioral consequences of JNK3 overexpression in the EC}


The memory capacity of AAV-JNK3 treated mice was assessed using the NORT and the MWM paradigm, three months after the AAV injection. Of note, no differences were observed in the locomotor activity between groups, indicating that behavioral performance differences between Sham- and AAV-injected mice are not due to locomotor activity alterations (Fig. 2a).

In the NORT, the percentage of time that mice invested exploring the new object against the old one (discrimination index) was the parameter used to evaluate cognitive performance. As shown in Fig. 2b, AAV-JNK3 mice displayed cognitive deficits in the NORT, as indicated by a significantly decreased discrimination index, failing to distinguish between an old and a novel object one hour after exposure to the old object.

The lack of differences observed among the groups in the escape latency during the visible platform phase indicates that all the animals are able to perform the task (data not shown). Moreover, swimming speed did not differ between groups (data not shown). As shown in Fig. 2c, no significant differences were observed among the groups during the invisible platform phase. The memory retention was evaluated at the beginning of the fourth, seven and tenth day and no significant differences were observed in any of those probe trials, in parallel with the results obtained in the adquisition phase (Fig. 2d).

\subsection{Effect of JNK3 overexpression on gliosis and neuroinflammation}

It has been described that chronic glial activation is a key factor contributing to cognitive impairment, and that activation of JNK results in neuroinflammation and subsequent neurodegeneration Thus, the impact of JNK3 overexpression in glial reactivity and markers of neuroinflammation were studied.

To address astrogliosis we focused on GFAP, a major intermediate filament protein specific to astrocytes. Our data showed a significant increase in GFAP immunoreactivity in AAV-JNK3 treated mice compared to Sham mice (Fig. 3a), not only in the injected area, i.e. the EC (Fig. 3a, medial EC and lateral EC panels), but also in the projection site, i.e. the Hp (Fig. 3a, Hp panel). When protein levels were assessed by immunoblotting, the same increase was observed in the EC (Fig. 3b), however the increase observed in the $\mathrm{Hp}$ did not reach statistical significance (Fig. 3c).

To address microgliosis, we focused on Iba1 for immunohistochemistry and CD11b for immunoblotting. In parallel with GFAP, Iba1 immunoreativity was increased in EC (Fig. 4a, medial EC and lateral EC panels), as well as the $\mathrm{Hp}$ (Fig. 4a, Hp panel). Again, when measured by immunoblotting, while a marked increase was observed in the EC (Fig. 4b), the increase in the Hp was not significant (Fig. 4c).

In order to address the implication of JNK3 in the release of inflammatory mediators, pro-inflammatory cytokines (TNFa, IL-1 $\beta$ and IL-6) mRNA expression was measured in both EC and Hp. All the cytokines studied showed a marked increase not only in EC but also in Hp (Fig. $5 a$, b and C), however, in the Hp only 
the increase in IL-6 expression reached statistical significance (Fig. 5c), probably due to the high variability of the data obtained in TNFa and IL-1 $\beta$ (Fig. $5 a$ and b).

\subsection{Effect of JNK3 overexpression on Tau pathology}

JNK3 can be autophosphorylated and subsequently it can induce Tau hyperphosphorylation [35]. In the present study, two different Tau conformations (ALZ50 and MC1) were analyzed, in an attempt to study the role of JNK3 in Tau aberrant misfolding [42-47]. Moreover, tauopathy brains present truncated Tau forms. Those truncated forms either at the $\mathrm{N}$-terminus or at both the $\mathrm{N}$ - and $\mathrm{C}$ - termini have been demonstrated to be able to adopt pathological conformations [48]. Specifically, in this study, the truncated form analyzed was Asp421, which has been demonstrated to be very prone to aggregation [49, 50]. Furthermore, Asp41 truncation is usually preceded by Tau Ser422 phosphorylation [51], that has also been analyzed in this work.

In the EC, AAV-JNK3 treated mice exhibited a strong increase on ALZ50 immunoreactivity (Fig. 6a), which was further corroborated by an augmented signal in immunoblotting (Fig. 6b). The same result was obtained for the other Tau conformational form, i.e. MC1 (Fig. $6 \mathrm{c}$ and d). In the same line, truncated Asp421 (Fig. 6e and f) and the preceding Ser422 phosphorylation (Fig. $6 \mathrm{~g}$ and $\mathrm{h}$ ) also appeared to be significantly increased. Consistent with a post-transcriptional regulation of Tau, total protein levels, normalized using actin, remained unaltered.

The same conformational changes were studied in the $\mathrm{Hp}$ and although a marked immunostaining increase was observed in ALZ50 (Fig. 7a and b), MC1 (Fig. 7c and d) and Asp421 (Fig. 7e and f), only Tau Ser422 reached significant increased levels (Fig. $7 \mathrm{~g}$ and $\mathrm{h}$ ). Once again, consistent with a posttranscriptional regulation of Tau, total Tau protein levels, normalized using actin, remained unaltered.

\section{Discussion}

A broad variety of illnesses involve the JNK family $[52,53]$. Indeed, JNKs are thought to be a critical mediator of neuronal response to stress, involving both neuronal survival and death under a variety of conditions [54]. There are at least ten JNK isoforms expressed from three genes, exhibiting differences in substrate and binding protein specificity [6]. Knock-out animal models disclosed different gene product features $[16,9]$, yet evidence for selective activation of endogenous JNKs is absent. Indeed, although many studies in the literature have addressed the cognitive and molecular consequences of JNK3 ablation in $A D$, to our knowledge, currently there is no study that analyzes the consequences of JNK3 overexpression on cognitive performance. Thus, the main aim of the present study was to assess the consequences of JNK overexpression, more specifically overexpression of the JNK3 isoform, i.e. the main isoform in the brain.

This work focuses on the EC as it is considered to be one of the key sites for the development of neurodegeneration. The EC is an essential area located in the medial temporal lobe, whose functions include long-term-memory. Interestingly, EC projects to Hp and it receives inputs from other cortical areas. 
The EC is divided in two main areas: the medial EC (MEC) and the lateral EC (LEC). Both MEC and LEC has shown to have different functional characteristics. The MEC superficial layers comprise several spatially modulated cell types, whereas the LEC's adjacent neurons exhibit only sparse spatial modulation [55-57] and somatosensory information [58-61]. The spatial information coming from the MEC together with the non-spatial information processed from the LEC are integrated in the EC [62-65]. $E C$ is one of the earliest affected areas in neurodegenerative disorders such as $A D$, indicating the essential participation of EC in cognition [66]. Although the reason behind this early EC impairment in AD is still unknown, a specific vulnerability to aging and AD of the EC neurons is hypothesized [67], that induces a significant neuronal death in this area during the first stages of the disease [68]. Noteworthy, amyloid protein and hyperphosphorylated Tau aggregation, i.e. the main AD histopathological characteristics, appear first in the EC in mild AD and are not disseminated to other areas such as the Hp until more advance stages of the disease [69]. Hence, it has been suggested that the neurodegeneration that starts in EC neurons is transferred to the $\mathrm{Hp}$, inducing the disruption of the cortical-hippocampal network in AD patients. In light of these important findings, in this study it was decided to induce JNK3 overexpression in both MEC and LEC, in order to elucidate if increased levels of JNK3 could lead to a cortical-hippocampal network dysfunction and ultimately to cognitive alterations. Furthermore, JNK3 overexpression was induced in wild type mice, in an attempt to mimic early stages of AD when amyloid plaque or neurofibrillary tangle accumulations are still absent.

Our results showed that although viral infection was conducted in EC (MEC and LEC), JNK3 overexpression is also observed in the Hp, concluding that changes in the EC can lead directly to downstream modifications in its main afferent areas, such as the $\mathrm{Hp}$, leading to aberrant network activity as it has been observed in mouse models and human $A D$ patients [70, 71]. More importantly, we demonstrated that JNK3 overexpression was associated with a behavioral impairment of associative memory, assessed by the NORT. A significant role in object recognition and novelty detection has already been assigned to the EC [72]. In particular, information from EC can be acquired in the Hp through the complex integration of spatial information coming from MEC with non-spatial input from the LEC $[64,65]$. Specifically, a population of LEC cells have been identified, some of them firing at the objects and other cells firing at places where objects were located on previous trials [72]. In addition, LEC is needed to recognize items encountered in a particular context [73] and the specific lesion of the LEC impairs the capacity to discriminate either novel object-place or novel object-place-context associations [73]. Therefore, in light of our results, it seems that the induction of JNK3 overexpression in the EC affects the integration of information in the $\mathrm{Hp}$, leading to cognitive deficiencies. On the contrary, no alterations were observed in the MWM task after JNK3 overexpression. The MWM is a classical test to assess spatial and thus hippocampus-dependent memory performance [74]. Therefore, our results suggest that the increase of JNK3 obtained in the Hp is not strong enough to induce a spatial learning impairment, as it occurs in early stages of AD. Probably, a higher JNK3 dissemination in the hippocampus is necessary to induce deficits in spatial learning

The proof that JNK accumulation is associated with inflammatory pathway activation [75] raises the main question of whether brain neuroinflammation is involved in the early behavioral deficits found in the 
present study after JNK3 overexpression induction. Inflammation is the first reaction from our body's immune system to pathogens or irritation and it is a two-edged sword. It protects tissue against invading agents under acute circumstances and encourages healing. On the other hand, it can cause severe damage to the host's own tissue if it is chronically maintained. While the CNS is recognized as an immune-privileged organ, there is growing evidence that inflammation is directly involved in the pathogenesis of a number of neurodegenerative diseases, including AD, multiple sclerosis (MS), and HIVassociated dementia $[76,77,78]$. Chronic inflammation-mediated tissue injury can be particularly damaging to the brain, as neurons are usually irreplaceable. In particular, it has been extensively demonstrated the involvement of astrocytes and microglia in the pathological process of AD. Indeed, it has been observed in AD animal models and patients that the cognitive deficiencies are accompanied by chronic glial activation and pro-inflammatory cytokine production [79]. Consequently, pathological markers indicative of astrogliosis and microgliosis are correlated with cognitive disturbances in $A D[80$, 81,82 ]. Increased levels of pro-inflammatory cytokines are detected in early phases of clinical AD patients and it is suggested that those cytokines contribute to the neurotoxicity observed in AD late stages [83, 84, $85,86]$. In agreement with those studies, our data demonstrated that overexpression of JNK3 induced all the pathological markers observed in early-stages of $A D$ brains, i.e., microgliosis, astrogliosis and proinflammatory cytokine (IL-1 $\beta$, IL-6, TNFa) release that could contribute to the cognitive deficiencies observed in the JNK3-induced mice. Interestingly, although all those markers were strongly increased in the EC (the injection area), neuroinflammation was milder in the Hp. This could also explain the absence of cognitive alterations in the MWM.

Apart of its central role in neuroinflammation, JNK kinase can participate in AD pathology by its implication in Tau phosphorylation and subsequent neurofibrillary tangles formation [87]. It has been demonstrated by in vitro experiments that JNK3 isoform can be autophosphorylated and then, it can contribute to Tau hyperphosphorylation [88]. Tau hyperphosphorylation induces its aberrant misfolding, following by its dissociation from microtubules and aggregation in neurofibrillary tangles. In order to study the implication of JNK3 on the conformation of Tau aberrant misfolding, two different conformations were studied: ALZ50 and MC1. ALZ-50 has been detected in brain homogenates [89] inside susceptible neurons [43, 89-92]. MC1 appeared to be a good marker for early aggregation of Tau protein, before the appearance of neurofibrillary tangles [93-95]. Another modification associated with Tau deposition in AD is truncation $[96,97]$. Several authors consider that Tau truncation in the C-terminus precedes Tau assembly in paired helical filaments [49, 50, 96-99] and truncation has been associated with early as well as late stages of AD pathology $[100,101,102,103]$. Interestingly, Tau truncation is frequently preceded by Tau Ser422 phosphorylation. In our hands, all the aberrant conformations studied (ALZ50, MC1, truncated Asp421 Tau and Tau Ser422) appeared to be strongly increased after JNK3 overexpression, suggesting that Tau misfolding and subsequent microtubule disaggregation could be also underlying the cognitive deficiencies observed in AAV-JNK3 mice. Noteworthy, the fact that in the Hp Tau misfolding assessment did not reach statistical significance might ground the lack of cognitive impairment in the MWM task. 
In summary, the data obtained in the present study indicate that activation of inflammatory signals and induction of Tau in vivo misfolding triggered by an enriched JNK3 environment is a significant early event during the progressive EC dysfunction. Therefore, JNK3 overexpression can lead to the triggering of cognitive dysfunction resulting in the dissemination of neurodegeneration from EC to $\mathrm{Hp}$ and may be at the origin of the changes observed in early stages of $A D$.

\section{Declarations}

\section{Acknowledgments}

Carlos G. Ardanaz is a recipient of a fellowship from Spanish Government (FPU).

\section{Funding}

The authors declare that no funds, grants, or other support were received during the preparation of this manuscript.

\section{Competing Interests}

The authors have no relevant financial or non-financial interests to disclose.

\section{Author Contributions}

All authors contributed to the study conception and design. Material preparation, data collection and analysis were performed by Carlos G. Ardanaz, Arantza Bejarano, Beatriz Echarte, Cristian Smerdou, Eva Martisova, Iván Martínez-Valbuena and Maite Solas. The first draft of the manuscript was written by Carlos G. Ardanaz and Maite Solas and all authors commented on previous versions of the manuscript. All authors read and approved the final manuscript.

\section{Data Availability}

The datasets generated during and/or analysed during the current study are available from the corresponding author on reasonable request.

\section{Ethics approval}

Experimental procedures were conducted in accordance with the European and Spanish regulations (2003/65/EC; 1201/2005) for the care and use of laboratory animals and approved by the Ethical Committee of University of Navarra (ethical protocol number 038-17).

\section{Consent to participate}

Not applicable

\section{Consent to publish}




\section{References}

1. Davis RJ (2000) Signal Transduction by the JNK Group of MAP Kinases. Cell 103:239-252. https://doi.org/10.1016/S0092-8674(00)00116-1

2. Cui J, Zhang M, Zhang YQ, Xu ZH (2007) JNK pathway: diseases and therapeutic potential. Acta Pharmacol Sin 28:601-608. https://doi.org/10.1111/j.1745-7254.2007.00579.x

3. Yarza R, Vela S, Solas M, Ramirez MJ (2016) c-Jun N-terminal Kinase (JNK) Signaling as a Therapeutic Target for Alzheimer's Disease. Front Pharmacol 6:321. https://doi.org/10.3389/fphar.2015.00321

4. Varona-Santos JL, Pileggi A, Molano RD, Sanabria NY, ljaz A, Atsushi M, Ichii H, Pastori RL, Inverardi L, Ricordi C, Fornoni A (2008) C-Jun N-terminal kinase 1 is deleterious to the function and survival of murine pancreatic islets. Diabetologia 51:2271-2280. https://doi.org/10.1007/s00125-008-1169-7

5. Kunde SA, Rademacher N, Tzschach A, Wiedersberg E, Ullmann R, Kalscheuer VM, Shoichet SA (2013) Characterisation of de novo MAPK10/JNK3 truncation mutations associated with cognitive disorders in two unrelated patients. Hum Genet 132:461-471. https://doi.org/10.1007/s00439-012$1260-5$

6. Gupta S, Barrett T, Whitmarsh AJ, Cavanagh J, Sluss HK, Dérijard B, Davis RJ (1996) Selective interaction of JNK protein kinase isoforms with transcription factors. EMBO J 15:2760-2770

7. Bogoyevitch MA, Ngoei KRW, Zhao TT, Yeap YYC, Ng DCH (2010) c-Jun N-terminal kinase (JNK) signaling: Recent advances and challenges. Biochim Biophys Acta 1804:463-475. https://doi.org/10.1016/J.BBAPAP.2009.11.002

8. Coffey ET (2014) Nuclear and cytosolic JNK signalling in neurons. Nat Rev Neurosci 15:285-299. https://doi.org/10.1038/nrn3729

9. Kuan CY, Yang DD, Samanta Roy DR, Davis RJ, Rakic P, Flavell RA (1999) The Jnk1 and Jnk2 protein kinases are required for regional specific apoptosis during early brain development. Neuron 22:667676

10. Waetzig V, Czeloth K, Hidding U, Mielke K, Kanzow M, Brecht S, Goetz M, Lucius R, Herdegen T, Hanisch UK (2005) c-Jun N-terminal kinases (JNKs) mediate pro-inflammatory actions of microglia. Glia 50:235-246. https://doi.org/ 10.1002/glia.20173

11. Eminel S, Roemer L, Waetzig V, Herdegen T (2008) C-Jun N-terminal kinases trigger both degeneration and neurite outgrowth in primary hippocampal and cortical neurons. J Neurochem 104:957-969. https://doi.org/10.1111/j.1471-4159.2007.05101.x

12. Bevilaqua LRM, Kerr DS, Medina JH, Izquierdo I, Cammarota M (2003) Inhibition of hippocampal Jun $\mathrm{N}$-terminal kinase enhances short-term memory but blocks long-term memory formation and retrieval of an inhibitory avoidance task. Eur J Neurosci 17:897-902. https://doi.org/10.1046/j.14609568.2003.02524.x 
13. Brecht S, Kirchhof R, Chromik A, Willesen M, Nicolaus T, Raivich G, Wessig J, Waetzig V, Goetz M, Claussen M, Pearse D, Kuan CY, Vaudano E, Behrens A, Wagner E, Flavell RA, Davis RJ, Herdegen T (2005) Specific pathophysiological functions of JNK isoforms in the brain. Eur J Neurosci 21:363377. https://doi.org/10.1111/j.1460-9568.2005.03857.x

14. Fu M, Holzbaur ELF (2013) JIP1 regulates the directionality of APP axonal transport by coordinating kinesin and dynein motors. J Cell Biol 202:495-508. https://doi.org/10.1083/jcb.201302078

15. Lee HM, Kim KS, Kim J (2014) A comparative study of the effects of inhibitory cytokines on human natural killer cells and the mechanistic features of transforming growth factor-beta. Cell Immunol 290:52-61. https://doi.org/10.1016/j.cellimm.2014.05.001

16. Yang DD, Kuan CY, Whitmarsh AJ, Rincón M, Zheng TS, Davis RJ, Rakic P, Flavell RA (1997) Absence of excitotoxicity-induced apoptosis in the hippocampus of mice lacking the Jnk3 gene. Nature 389:865-870. https://doi.org/10.1038/39899

17. Okazawa H, Estus S (2002) The JNK/c-Jun cascade and Alzheimer's disease. Am J Alzheimers Dis Other Demen 17:79-88. https://doi.org/10.1177/153331750201700209

18. Sahara N, Murayama M, Lee B, Park JM, Lagalwar S, Binder LI, Takashima A (2008) Active c-jun Nterminal kinase induces caspase cleavage of tau and additional phosphorylation by GSK-3-beta is required for tau aggregation. Eur J Neurosci 27:2897-2906. http://doi.org/10.1111/j.14609568.2008.06258.x

19. Zhang F, Jiang L (2015) Neuroinflammation in Alzheimer's disease. Neuropsychiatr Dis Treat 11:243. https://doi.org/10.2147/NDT.S75546

20. Kempuraj D, Thangavel R, Natteru PA, Selvakumar GP, Saeed D, Zahoor H, Zaheer S, lyer SS, Zaheer A (2016) Neuroinflammation induces neurodegeneration. J Neurol Neurosurg Spine 1:1003

21. Waetzig V, Zhao Y, Herdegen T (2006) The bright side of JNKs-Multitalented mediators in neuronal sprouting, brain development and nerve fiber regeneration. Prog Neurobiol 80:84-97. https://doi.org/10.1016/j.pneurobio.2006.08.002

22. Jang S, Kelley KW, Johnson RW (2008) Luteolin reduces IL-6 production in microglia by inhibiting JNK phosphorylation and activation of AP-1. Proc Natl Acad Sci U S A 105:7534-7539. https://doi.org/10.1073/pnas.0802865105

23. Pocivavsek A, Burns MP, Rebeck GW (2009) Low-density lipoprotein receptors regulate microglial inflammation through c-Jun N-terminal kinase. Glia 57:444-453. https://doi.org/10.1002/glia.20772

24. Trojanowski JQ, Lee VMY (2005) Rous-Whipple Award Lecture. The Alzheimer's brain: finding out what's broken tells us how to fix it. The Am J Pathol 167:1183-1188. https://doi.org/10.1016/s00029440(10)61206-0

25. Querfurth HW, LaFerla FM (2010) Alzheimer's disease. N Engl J Med. https://doi.org/10.1056/NEJMra0909142. 362:329 - 44

26. Ferrer I, Blanco R, Carmona M, Puig B (2001) Phosphorylated mitogen-activated protein kinase (MAPK/ERK-P), protein kinase of $38 \mathrm{kDa}$ (p38-P), stress-activated protein kinase (SAPK/JNK-P), and calcium/calmodulin-dependent kinase II (CaM kinase II) are differentially expressed in tau deposits 
in neurons and glial cells in tauopathies. J Neural Transm 108:1397-1415. https://doi.org/10.1007/s007020100016

27. Ferrer I, Blanco R, Carmona M, Puig B, Domínguez I, Viñals F (2002) Active, phosphorylationdependent MAP kinases, MAPK/ERK, SAPK/JNK and p38, and specific transcription factor substrates are differentially expressed following systemic administration of kainic acid to the adult rat. Acta Neuropathol 103:391-407. https://doi.org/10.1007/s00401-001-0481-9

28. Yoon SO, Park DJ, Ryu JC, Ozer HG, Tep C, Shin YJ, Lim TH, Pastorino L, Kunwar AJ, Walton JC, Nagahara AH, Lu KP, Nelson RJ, Tuszynski MH, Huang K (2012) JNK3 Perpetuates Metabolic Stress Induced by Aß Peptides. Neuron 75:824-837. https://doi.org/10.1016/j.neuron.2012.06.024

29. Mazzitelli S, Xu P, Ferrer I, Davis RJ, Tournier C (2011) The Loss of c-Jun N-Terminal Protein Kinase Activity Prevents the Amyloidogenic Cleavage of Amyloid Precursor Protein and the Formation of Amyloid Plaques In Vivo. J Neurosci 31:16969-16976. https://doi.org/10.1523/JNEUROSCI.449111.2011

30. Reynolds CH, Betts JC, Blackstock WP, Nebreda AR, Anderton BH (2002) Phosphorylation Sites on Tau Identified by Nanoelectrospray Mass Spectrometry. J Neurochem 74:1587-1595. https://doi.org/10.1046/j.1471-4159.2000.0741587.x

31. Savage MJ, Lin YG, Ciallella JR, Flood DG, Scott RW (2002) Activation of c-Jun N-terminal kinase and p38 in an Alzheimer's disease model is associated with amyloid deposition. J Neurosci 22:3376-3385. https://doi.org/20026352

32. Tran HT, Sanchez L, Brody DL (2012) Inhibition of JNK by a Peptide Inhibitor Reduces Traumatic Brain Injury-Induced Tauopathy in Transgenic Mice. J Neuropathol Exp Neurol 71:116-129. https://doi.org/10.1097/NEN.0b013e3182456aed

33. Braithwaite SP, Schmid RS, He DN, Sung ML, Cho S, Resnick L, Monaghan MM, Hirst WD, Essrich C, Reinhart PH, Lo DC (2010) Inhibition of c-Jun kinase provides neuroprotection in a model of Alzheimer's disease. Neurobiol Dis 39:311-317. https://doi.org/10.1016/j.nbd.2010.04.015

34. Sclip A, Antoniou X, Colombo A, Camici GG, Pozzi L, Cardinetti D, Feligioni M, Veglianese P, Bahlmann FH, Cervo L, Balducci C, Costa C, Tozzi A, Calabresi P, Forloni G, Borsello T (2011) c-Jun N-terminal Kinase Regulates Soluble $A \beta$ Oligomers and Cognitive Impairment in AD Mouse Model. J Biol Chem 286:43871-43880. https://doi.org/10.1074/jbc.M111.297515

35. Yoshida H, Hastie CJ, McLauchlan H, Cohen P, Goedert M (2004) Phosphorylation of microtubuleassociated protein tau by isoforms of c-Jun N-terminal kinase (JNK). J Neurochem 90:352-358. https://doi.org/10.1111/j.1471-4159.2004.02479.x

36. Ferrer I, Pastor P, Rey MJ, Muñoz E, Puig B, Pastor E, Oliva R, Tolosa E (2003) Tau phosphorylation and kinase activation in familial tauopathy linked to deln296 mutation. Neuropathol Appl Neurobiol 29:23-34. https://doi.org/10.1046/j.1365-2990.2003.00435.x

37. de Leon MJ, Convit A, Wolf OT, Tarshish CY, DeSanti S, Rusinek H, Tsui W, Kandil E, Scherer AJ, Roche A, Imossi A, Thorn E, Bobinski M, Caraos C, Lesbre P, Schlyer D, Poirier J, Reisberg B, Fowler J (2001) Prediction of cognitive decline in normal elderly subjects with 2-[18F]fluoro-2-deoxy-D- 
glucose/positron-emission tomography (FDG/PET). Proc Natl Acad Sci U S A 98:10966-10971. https://doi.org/10.1073/pnas.191044198

38. deToledo-Morrell L, Stoub TR, Wang C (2007) Hippocampal atrophy and disconnection in incipient and mild Alzheimer's disease. Prog Brain Res 163:741-753. https://doi.org/10.1016/S00796123(07)63040-4

39. Hyman BT, Van Hoesen GW, Kromer LJ, Damasio AR (1986) Perforant pathway changes and the memory impairment of Alzheimer's disease. Ann Neurol 20:472-481. https://doi.org/10.1002/ana.410200406

40. Pignataro D, Sucunza D, Vanrell L, Lopez-Franco E, Dopeso-Reyes IG, Vales A, Hommel M, Rico AJ, Lanciego JL, Gonzalez-Aseguinolaza G (2017) Adeno-Associated Viral Vectors Serotype 8 for CellSpecific Delivery of Therapeutic Genes in the Central Nervous System. Front Neuroanat 11:2. https://doi.org/10.3389/fnana.2017.00002

41. Watson C, Paxinos G (2010) Chemoarchitectonic atlas of the mouse brain. Academic Press, San Diego

42. Nukina N, Kosik KS, Selkoe DJ (1988) The monoclonal antibody, Alz 50, recognizes tau proteins in Alzheimer's disease brain. Neurosci Lett 87:240-246. https://doi.org/10.1016/0304-3940(88)904557

43. Tabatonm M, Whitehouse PJ, Perry G, Davies P, Autilio-Gambetti L, Gambetti P (1988) Alz 50 recognizes abnormal filaments in Alzheimer's disease and progressive supranuclear palsy. Ann Neurol 24:407-413. https://doi.org/10.1002/ana.410240309

44. Carmel G, Mager EM, Binder LI, Kuret J (1996) The Structural Basis of Monoclonal Antibody Alz50's Selectivity for Alzheimer's Disease Pathology. J Biol Chem 271:32789-32795. https://doi.org/10.1074/jbc.271.51.32789

45. Jarero-Basulto JJ, Luna-Muñoz J, Mena R, Kristofikova Z, Ripova D, Perry G, Binder LI, Garcia-Sierra F (2013) Proteolytic Cleavage of Polymeric Tau Protein by Caspase-3: Implications for Alzheimer Disease. J Neuropathol Exp Neurol 72:1145-1161. https://doi.org/10.1097/NEN.0000000000000013

46. Mead E, Kestoras D, Gibson Y, Hamilton L, Goodson R, Jones S, Eversden S, Davies P, O'Neill M, Hutton M, Szekeres P, Wolak J (2016) Halting of Caspase Activity Protects Tau from MC1Conformational Change and Aggregation. J Alzheimers Dis 54:1521-1538. https://doi.org/10.3233/JAD-150960

47. Vitale F, Giliberto L, Ruiz S, Steslow K, Marambaud P, d’Abramo C (2018) Anti-tau conformational scFv MC1 antibody efficiently reduces pathological tau species in adult JNPL3 mice. Acta Neuropathol Commun 6:82. https://doi.org/10.1186/s40478-018-0585-2

48. Vechterova L, Kontsekova E, Zilka N, Ferencik M, Ravid R, Novak M (2003) DC11: a novel monoclonal antibody revealing Alzheimer's disease-specific tau epitope. Neuro Rep 14:87-91. doi:10.1097/00001756-200301200-00017 
49. Abraha A, Ghoshal N, Gamblin TC, Cryns V, Berry RW, Kuret J, Binder LI (2000) C-terminal inhibition of tau assembly in vitro and in Alzheimer's disease. J Cell Sci 113:3737-3745

50. Berry RW, Abraha A, Lagalwar S, LaPointe N, Gamblin TC, Cryns VL, Binder LI (2003) Inhibition of Tau Polymerization by Its Carboxy-Terminal Caspase Cleavage Fragment. Biochemistry 42:8325-8331. doi:10.1021/bi027348m

51. Guillozet-Bongaarts AL, Cahill ME, Cryns VL, Reynolds MR, Berry RW, Binder LI (2006) Pseudophosphorylation of tau at serine 422 inhibits caspase cleavage: in vitro evidence and implications for tangle formation in vivo. J Neurochem 97:1005-1014. doi:10.1111/j.14714159.2006.03784.x

52. Kyriakis JM, Avruch J (2001) Mammalian Mitogen-Activated Protein Kinase Signal Transduction Pathways Activated by Stress and Inflammation. Physiol Rev 81:807-869. https://doi.org/10.1152/physrev.2001.81.2.807

53. Kyriakis JM, Banerjee P, Nikolakaki E, Dai T, Rubie EA, Ahmad MF, Avruch J, Woodgett JR (1994) The stress-activated protein kinase subfamily of c-Jun kinases. Nature 369:156-160. https://doi.org/10.1038/369156a0

54. Herdegen T, Skene P, Bähr M (1997) The c-Jun transcription factor-bipotential mediator of neuronal death, survival and regeneration. Trends Neurosci 20(5):227-231. https://doi.org/10.1016/s01662236(96)01000-4

55. Fyhn M, Molden S, Witter MP, Moser El, Moser MB (2004) Spatial Representation in the Entorhinal Cortex. Science 305:1258-1264. https://doi.org/10.1126/science.1099901

56. Hafting T, Fyhn M, Molden S, Moser MB, Moser El (2005) Microstructure of a spatial map in the entorhinal cortex. Nature 436:801-806. https://doi.org/10.1038/nature03721

57. Sargolini F, Fyhn M, Hafting T, McNaughton BL, Witter MP, Moser MB, Moser El (2006) Conjunctive Representation of Position, Direction, and Velocity in Entorhinal Cortex. Science 312:758-762. https://doi.org/10.1126/science.1125572

58. Burwell RD (2000) The Parahippocampal Region: Corticocortical Connectivity. Ann N Y Acad Sci 911:25-42. https://doi.org/10.1111/j.1749-6632.2000.tb06717.x

59. Naber PA, Witter MP, Lopes da Silva FH (2000) Differential distribution of barrel or visual cortex. Evoked responses along the rostro-caudal axis of the peri- and postrhinal cortices. Brain Res 877:298-305. https://doi.org/10.1016/s0006-8993(00)02694-9

60. Kerr KM, Agster KL, Furtak SC, Burwell RD (2007) Functional neuroanatomy of the parahippocampal region: The lateral and medial entorhinal areas. Hippocampus 17:697-708. https://doi.org/10.1002/hipo.20315

61. Knierim JJ, Lee I, Hargreaves EL (2006) Hippocampal place cells: Parallel input streams, subregional processing, and implications for episodic memory. Hippocampus 16:755-764. https://doi.org/10.1002/hipo.20203

62. Manns JR, Eichenbaum H (2006) Evolution of declarative memory. Hippocampus 16:795-808. https://doi.org/10.1002/hipo.20205 
63. Lisman JE (2007) Role of the dual entorhinal inputs to hippocampus: a hypothesis based on cue/action (non-self/self) couplets. Prog Brain Res 163:615-625. https://doi.org/10.1016/S00796123(07)63033-7

64. Moser El, Kropff E, Moser MB (2008) Place Cells, Grid Cells, and the Brain's Spatial Representation System. Annu Rev Neurosci 31:69-89. https://doi.org/10.1146/annurev.neuro.31.061307.090723

65. Stranahan AM, Mattson MP (2010) Selective vulnerability of neurons in layer II of the entorhinal cortex during aging and Alzheimer's disease. Neural Plast 108190. https://doi.org/10.1155/2010/108190

66. Mattson MP, Magnus T (2006) Ageing and neuronal vulnerability. Nat Rev Neurosci 7(4):278-294. https://doi.org/10.1038/nrn1886

67. Gómez-Isla T, Price JL, McKeel DW, Morris JC, Growdon JH, Hyman BT (1996) Profound loss of layer Il entorhinal cortex neurons occurs in very mild Alzheimer's disease. J Neurosci 16:4491-4500. https://doi.org/10.1523/JNEUROSCl.16-14-04491.1996

68. Braak H, Braak E (1991) Neuropathological stageing of Alzheimer-related changes. Acta Neuropathol 82:239-259. https://doi.org/10.1007/BF00308809

69. Palop JJ, Jones B, Kekonius L, Chin J, Yu GQ, Raber J, Masliah E, Mucke L (2003) Neuronal depletion of calcium-dependent proteins in the dentate gyrus is tightly linked to Alzheimer's disease-related cognitive deficits. Proc Natl Acad Sci U S A 100:9572-9577. https://doi.org/10.1073/pnas.1133381100

70. Scarmeas N, Honig LS, Choi H, Cantero J, Brandt J, Blacker D, Albert M, Amatniek JC, Marder K, Bell K, Hauser WA, Stern Y (2009) Seizures in Alzheimer Disease. Arch Neurol 66:992-997. https://doi.org/10.1001/archneurol.2009.130

71. Tsao A, Moser MB, Moser El (2013) Traces of experience in the lateral entorhinal cortex. Curr Biol 23:399-405. https://doi.org/10.1016/j.cub.2013.01.036

72. Wilson DIG, Langston RF, Schlesiger MI, Wagner M, Watanabe S, Ainge JA (2013) Lateral entorhinal cortex is critical for novel object-context recognition. Hippocampus 23:352-366. https://doi.org/10.1002/hipo.22095

73. Morris R (1984) Developments of a water-maze procedure for studying spatial learning in the rat. J Neurosci Methods 11:47-60. https://doi.org/10.1016/0165-0270(84)90007-4

74. Heppner FL, Ransohoff RM, Becher B (2015) Immune attack: the role of inflammation in Alzheimer disease. Nat Rev Neurosci 16:358-372. https://doi.org/10.1038/nrn3880

75. Raine CS (1994) Multiple Sclerosis: Immune System Molecule Expression in the Central Nervous System. J Neuropathol Exp Neurol 53:328-337. https://doi.org/10.1097/00005072-19940700000002

76. Banati RB, Daniel SE, Blunt SB (1998) Glial pathology but absence of apoptotic nigral neurons in long-standing Parkinson's disease. Mov Disord 13:221-227. https://doi.org/10.1002/mds.870130205 
77. McGeer PL, Itagaki S, Boyes BE, McGeer EG (1988) Reactive microglia are positive for HLA-DR in the substantianigra of Parkinson's and Alzheimer's disease brains. Neurology 38:1285-1291. https://doi.org/10.1212/wnl.38.8.1285

78. Hoozemans JJM, Veerhuis R, Rozemuller JM, Eikelenboom P (2006) Neuroinflammation and regeneration in the early stages of Alzheimer's disease pathology. Int J Dev Neurosci 24:157-165. https://doi.org/10.1016/j.ijdevneu.2005.11.001

79. Jimenez S, Baglietto-Vargas D, Caballero C, Moreno-Gonzalez I, Torres M, Sanchez-Varo R, Ruano D, Vizuete M, Gutierrez A, Vitorica J (2008) Inflammatory Response in the Hippocampus of PS1M146L/APP751SL Mouse Model of Alzheimer's Disease: Age-Dependent Switch in the Microglial Phenotype from Alternative to Classic. J Neurosci 28:11650-11661. https://doi.org/10.1523/JNEUROSCI.3024-08.2008

80. Heneka MT, Kummer MP, Stutz A, Delekate A, Schwartz S, Vieira-Saecker A, Griep A, Axt D, Remus A, Tzeng TC, Gelpi E, Halle A, Korte M, Latz E, Golenbock DT (2013) NLRP3 is activated in Alzheimer's disease and contributes to pathology in APP/PS1 mice. Nature 493:674-678. https://doi.org/10.1038/nature11729

81. Calsolaro V, Edison P (2016) Neuroinflammation in Alzheimer's disease: Current evidence and future directions. Alzheimers Dement 12:719-732. https://doi.org/10.1016/j.jalz.2016.02.010

82. McGeer EG, McGeer PL (1994) Inflammatory Cytokines in the CNS. CNS Drugs 7:214-228

83. Tarkowski E, Andreasen N, Tarkowski A, Blennow K (2003) Intrathecal inflammation precedes development of Alzheimer's disease. J Neurol Neurosurg Psychiatry 74:1200-1205. https://doi.org/10.1136/jnnp.74.9.1200

84. Wan Y, Xu J, Meng F, Bao Y, Ge Y, Lobo N, Vizcaychipi MP, Zhang D, Gentleman SM, Maze M, Ma D (2010) Cognitive decline following major surgery is associated with gliosis, $\beta$-amyloid accumulation, and $\tau$ phosphorylation in old mice. Crit Care Med 38:2190-2198. https://doi.org/10.1097/CCM.0b013e3181f17bcb

85. Rubio-Perez JM, Morillas-Ruiz JM (2012) A review: inflammatory process in Alzheimer's disease, role of cytokines. ScientificWorldJournal 2012:756357. https://doi.org/10.1100/2012/756357

86. Lagalwar S, Guillozet-Bongaarts AL, Berry RW, Binder LI (2006) Formation of Phospho-SAPK/JNK Granules in the Hippocampus Is an Early Event in Alzheimer Disease. J Neuropathol Exp Neurol 65:455-464. https://doi.org/10.1097/01.jnen.0000229236.98124.d8

87. Vogel J, Anand VS, Ludwig B, Nawoschik S, Dunlop J, Braithwaite SP (2009) The JNK pathway amplifies and drives subcellular changes in tau phosphorylation. Neuropharmacology 57:539-550. https://doi.org/10.1016/J.NEUROPHARM.2009.07.021

88. Wolozin B, Pruchnicki A, Dickson D, Davies $P$ (1986) A neuronal antigen in the brains of Alzheimer patients. Science 232:648-650. https://doi.org/10.1126/science.3083509

89. Hyman BT, Van Hoesen GW, Wolozin BL, Davies P, Kromer LJ, Damasio AR (1988) Alz-50 Antibody recognizes alzheimer-related neuronal changes. Ann Neurol 23:371-379. https://doi.org/10.1002/ana.410230410 
90. Rye DB, Leverenz J, Greenberg SG, Davies P, Saper CB (1993) The distribution of Alz-50 immunoreactivity in the normal human brain. Neuroscience 56:109-127. https://doi.org/10.1016/0306-4522(93)90567-Y

91. Braak E, Braak H, Mandelkow EM (1994) A sequence of cytoskeleton changes related to the formation of neurofibrillary tangles and neuropil threads. Acta Neuropathol 87:554-567. https://doi.org/10.1007/bf00293315

92. Uboga NV, Price JL (2000) Formation of diffuse and fibrillar tangles in aging and early Alzheimer's disease. Neurobiol Aging 21:1-10. https://doi.org/10.1016/s0197-4580(00)00091-9

93. Weaver CL, Espinoza M, Kress Y, Davies $P$ (2000) Conformational change as one of the earliest alterations of tau in Alzheimer's disease. Neurobiol Aging 21:719-727. https://doi.org/10.1016/s0197-4580(00)00157-3

94. Wischik CM, Novak M, Edwards PC, Klug A, Tichelaar W, Crowther RA (1988) Structural characterization of the core of the paired helical filament of Alzheimer disease. Proc Natl Acad Sci $U$ S A 85:4884-4888. https://doi.org/10.1073/pnas.85.13.4884

95. Wischik CM, Novak M, Thøgersen HC, Edwards PC, Runswick MJ, Jakes R, Walker JE, Milstein C, Roth M, Klug A (1988) Isolation of a fragment of tau derived from the core of the paired helical filament of Alzheimer disease. Proc Natl Acad Sci U S A 85:4506-4510. https://doi.org/10.1073/pnas.85.12.4506

96. Novak M, Jakes R, Edwards PC, Milstein C, Wischik CM (1991) Difference between the tau protein of Alzheimer paired helical filament core and normal tau revealed by epitope analysis of monoclonal antibodies 423 and 7.51. Proc Natl Acad Sci U S A 88:5837-5841. https://doi.org/10.1073/pnas.88.13.5837

97. Novak M, Kabat J, Wischik CM (1993) Molecular characterization of the minimal protease resistant tau unit of the Alzheimer's disease paired helical filament. EMBO J 12:365-370

98. Bondareff W, Harrington C, Wischik CM, Hauser DL, Roth M (1994) Immunohistochemical staging of neurofibrillary degeneration in Alzheimer's disease. J Neuropathol Exp Neurol 53:158-164. https://doi.org/10.1097/00005072-199403000-00007

99. Mena R, Edwards PC, Harrington CR, Mukaetova-Ladinska EB, Wischik CM (1996) Staging the pathological assembly of truncated tau protein into paired helical filaments in Alzheimer's disease. Acta Neuropathol 91:633-641. https://doi.org/10.1007/s004010050477

100. Mena R, Wischik CM, Novak M, Milstein C, Cuello AC (1991) A Progressive Deposition of Paired Helical Filaments (PHF) in the Brain Characterizes the Evolution of Dementia in Alzheimer's Disease. J Neuropathol Exp Neurol 50:474-490. https://doi.org/10.1097/00005072-199107000-00008

101. García-Sierra F, Wischik CM, Harrington CR, Luna-Muñoz J, Mena R (2001) Accumulation of Cterminally truncated tau protein associated with vulnerability of the perforant pathway in early stages of neurofibrillary pathology in Alzheimer's disease. J Chem Neuroanat 22:65-77. https://doi.org/10.1016/s0891-0618(01)00096-5 
102. 102. Mena R, Wischik CM, Novak M, Milstein C, Cuello AC (1991) A Progressive Deposition of Paired Helical Filaments (PHF) in the Brain Characterizes the Evolution of Dementia in Alzheimer's Disease. J Neuropathol Exp Neurol 50: 474-490. https://doi.org/10.1097/00005072-199107000-00008

103. 103. García-Sierra F, Wischik CM, Harrington CR, Luna-Muñoz J, Mena R (2001) Accumulation of Cterminally truncated tau protein associated with vulnerability of the perforant pathway in early stages of neurofibrillary pathology in Alzheimer's disease. J Chem Neuroanat 22:65-77. https://doi.org/10.1016/s0891-0618(01)00096-5

\section{Figures}


a
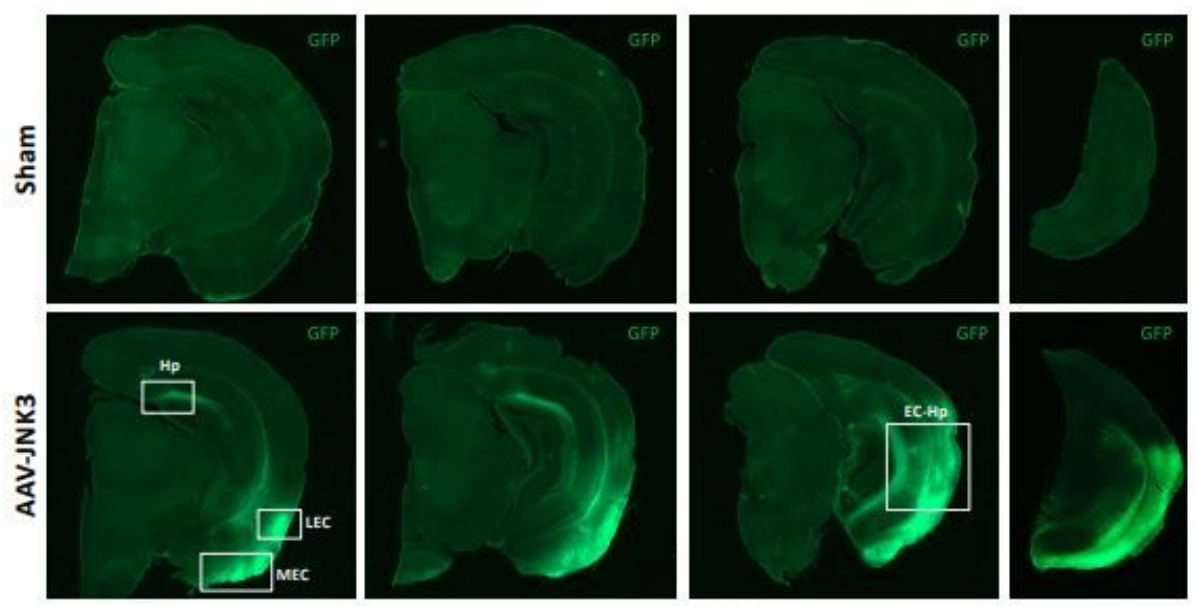

b

Medial EC

Lateral EC

$\mathrm{Hp}$

EC-Hp
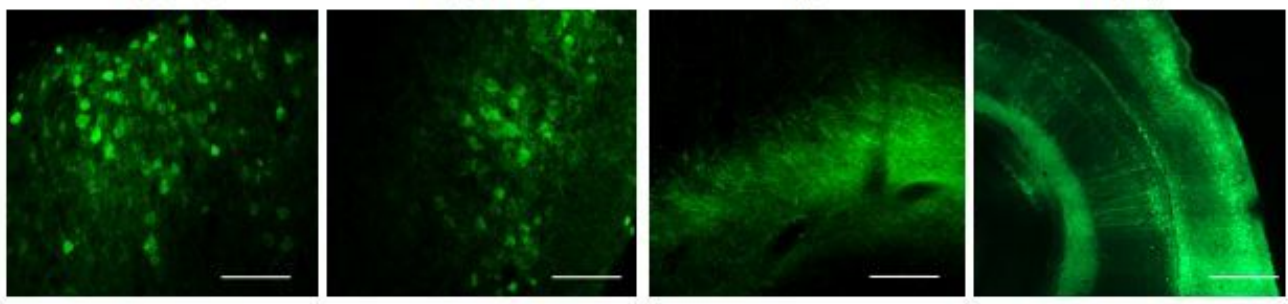

C

d
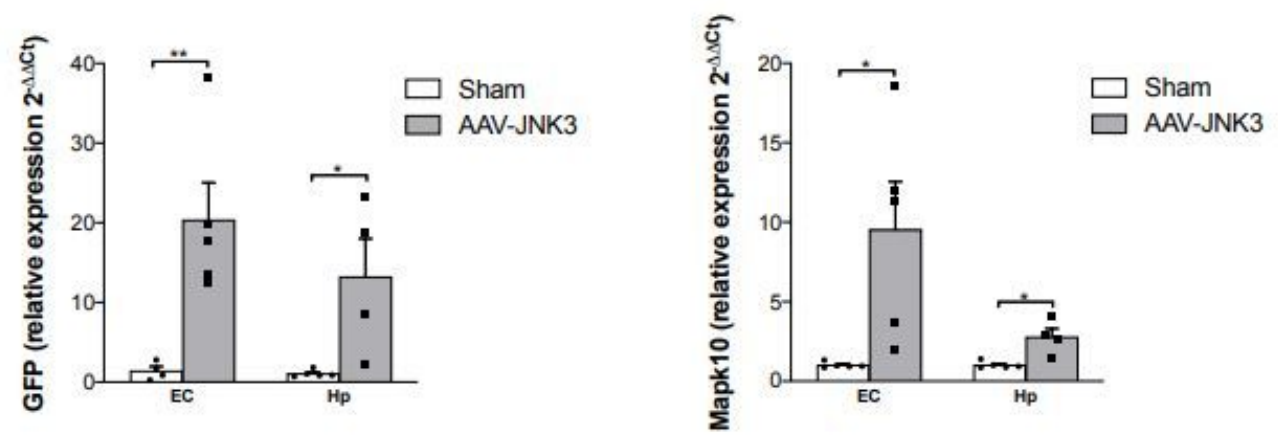

e

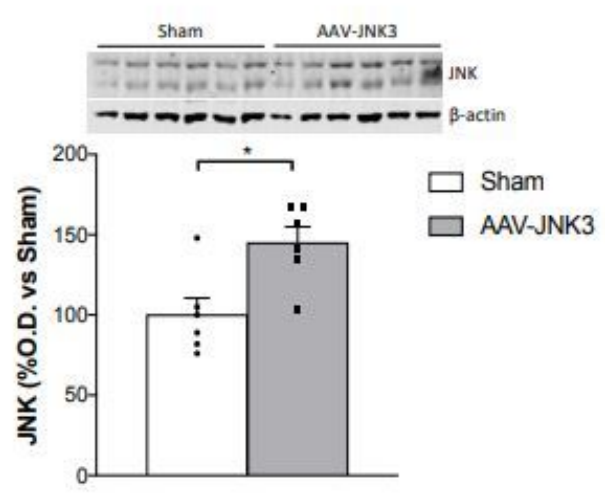

f

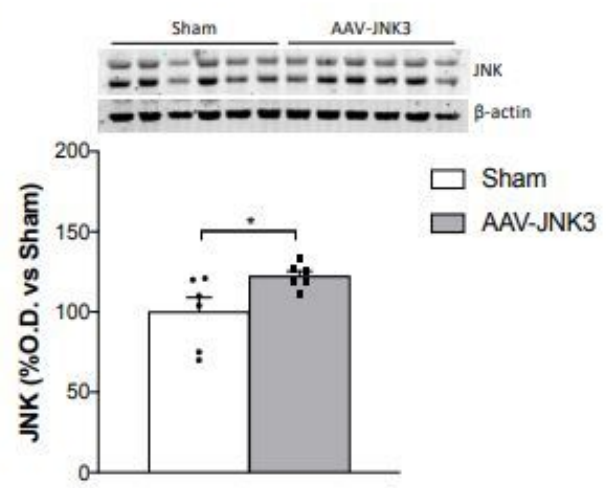

\section{Figure 1}

Analysis of the transduction efficacy of the AAV. a) Serial slices representative of GFP expression in Sham and AAV-JNK3 injected mice. White boxes indicate key areas magnified in figure 4B. b) GFP expression in medial EC, lateral EC, $\mathrm{Hp}$ and the projections from EC to Hp. Scale bar: $100 \mu \mathrm{M}$. c) GFP mRNA relative expression in EC (Student's $t$ test, $t=3.552,{ }^{*} \mathrm{p}<0.01 ; \mathrm{n}=5$ ) and Hp (Student's t test, $\mathrm{t}=2.887$, ${ }^{*} p<0.05 ; n=5$ ). d) MAPK10 mRNA relative expression in the EC (Student's t test, $t=2,825,{ }^{*} p<0.05 ; n=5$ ) and 
Hp (Student's t test, $\mathrm{t}=3.670,{ }^{*} \mathrm{p}<0.05 ; \mathrm{n}=5$ ). e) JNK protein presence in EC (Student's $\mathrm{t}$ test, $\mathrm{t}=3.110$, $\left.{ }^{*} p<0.05 ; n=6\right)$. f) JNK protein presence in Hp (Student's t test, $t=2.315,{ }^{*} p<0.05 ; n=6$ ). Results are shown as mean \pm SEM. In panels e and $f$ figures show optical density (O.D.) values percentage and an illustrative image of the blotting. EC: entorhinal cortex; Hp: hippocampus; O.D.: optical density.

a

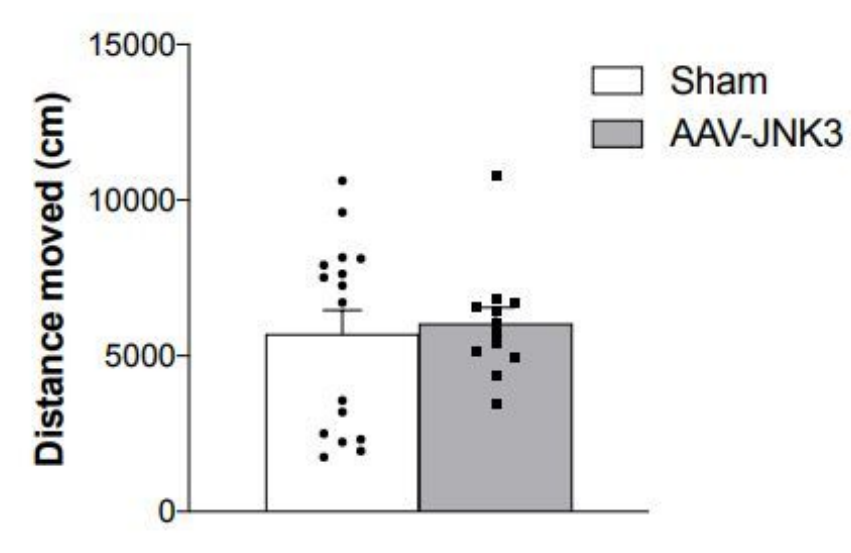

c

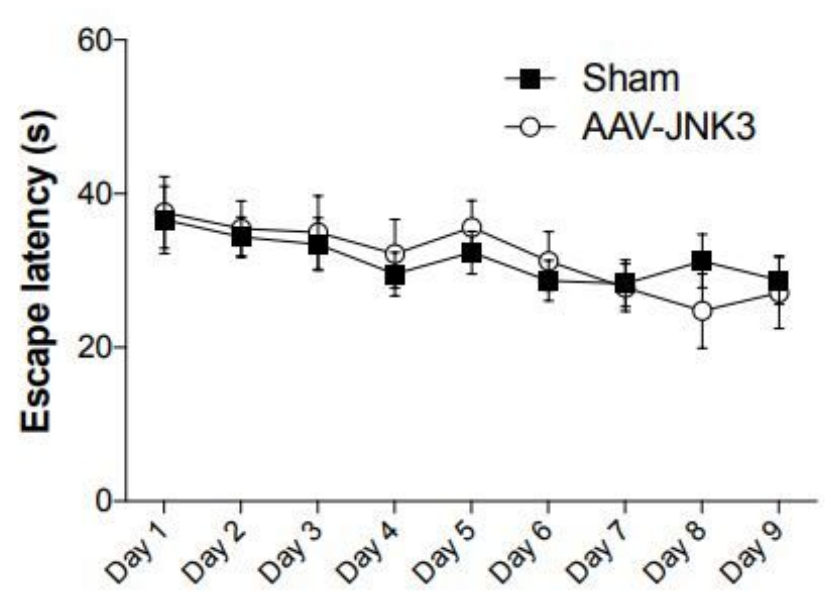

b

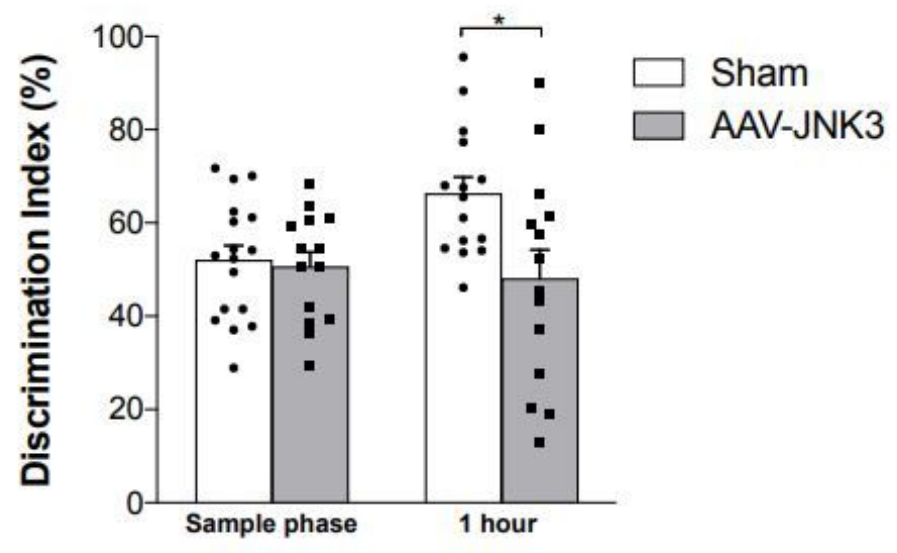

d

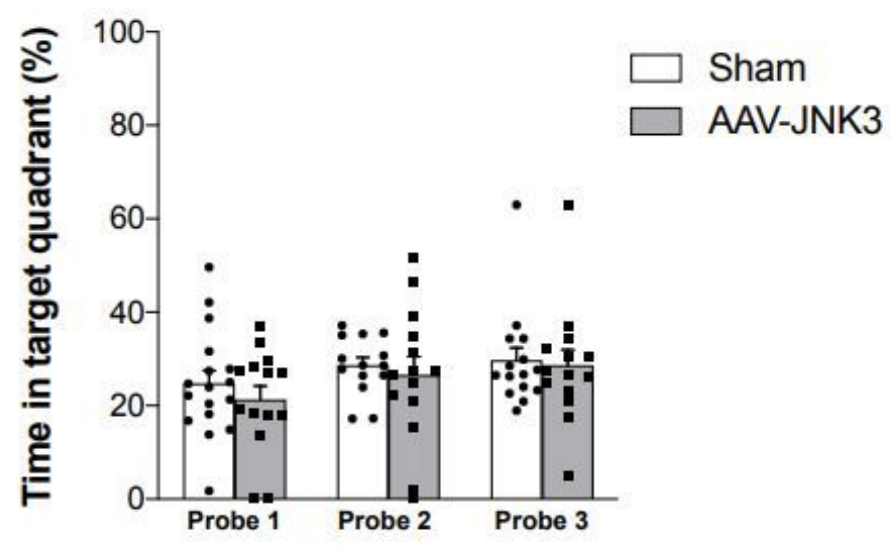

\section{Figure 2}

Behavioral consequences of JNK3 overexpression in the EC. a) Locomotor activity $(n=14-15)$. b) Cognitive performance in novel object recognition test (NORT). Data displays discrimination index (time exploring the new object / total exploration time $\times 100$ ) (Student's $t$ test, $\left.t=2.582,{ }^{*} p<0.05 ; n=14-15\right) . c$ ) and d) cognitive performance assessed by Morris water maze (MWM) acquisition phase and retention phase respectively $(n=14-15)$. Data are showed as mean \pm SEM. EC: entorhinal cortex. 
a
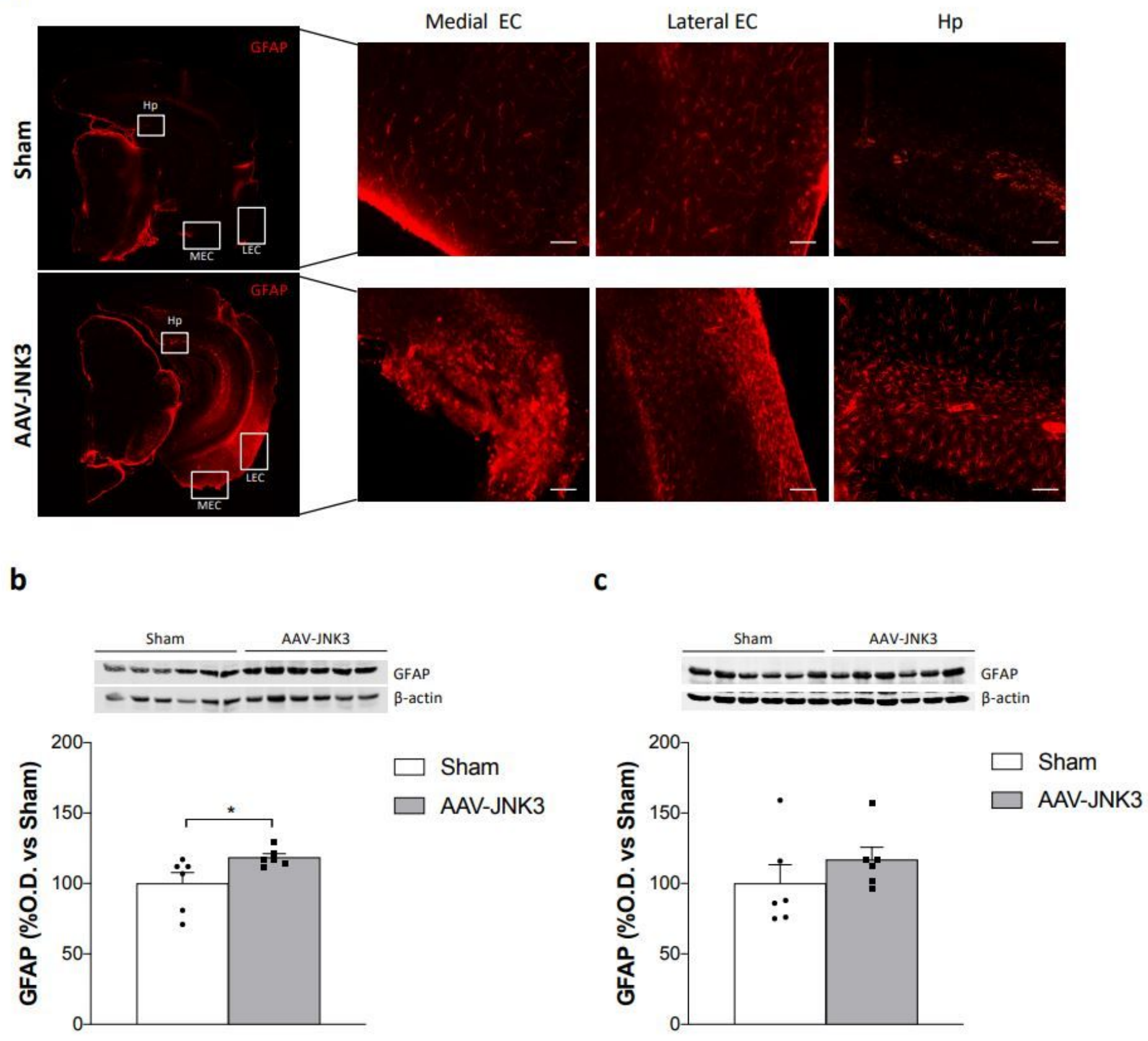

Figure 3

Effect of JNK3 overexpression on astrogliosis. a) GFAP expression in Sham and AAV-JNK3 injected mice and magnification images of medial EC, lateral EC and Hp. Scale bar: $100 \mu \mathrm{M}$. b) GFAP protein levels in the EC (Student's $t$ test, $\left.t=2.256,{ }^{*} p<0.05 ; n=6\right)$. c) GFAP protein levels in the Hp (Student's $t$ test, $t=1.065$, $p>0.05 ; n=6)$. Results are shown as mean \pm SEM. In panels $b$ and $c$ figures show density (O.D.) values percentage and an illustrative image of the blotting. EC: entorhinal cortex; Hp: hippocampus; O.D.: optical density. 
a

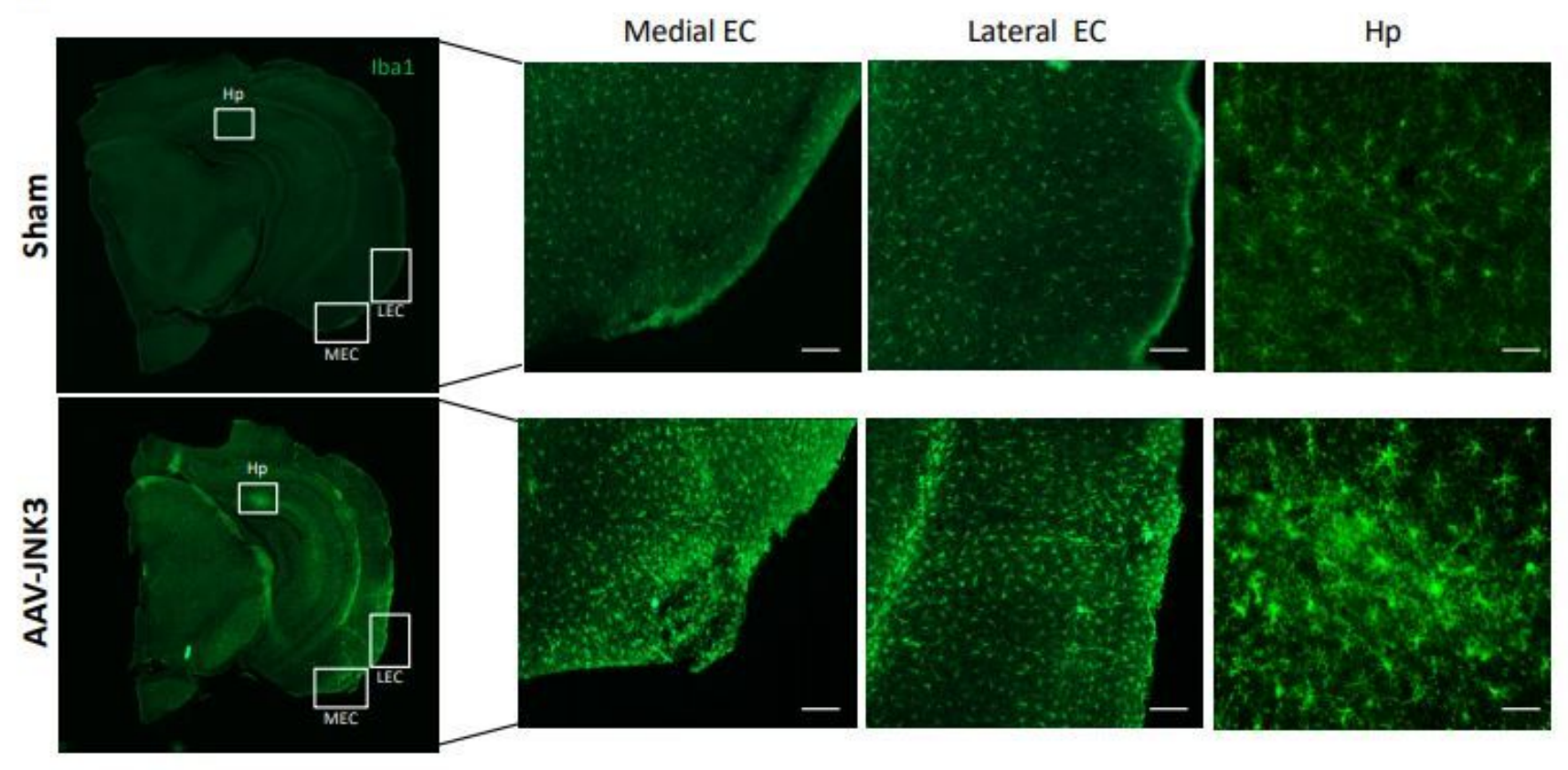

b

C
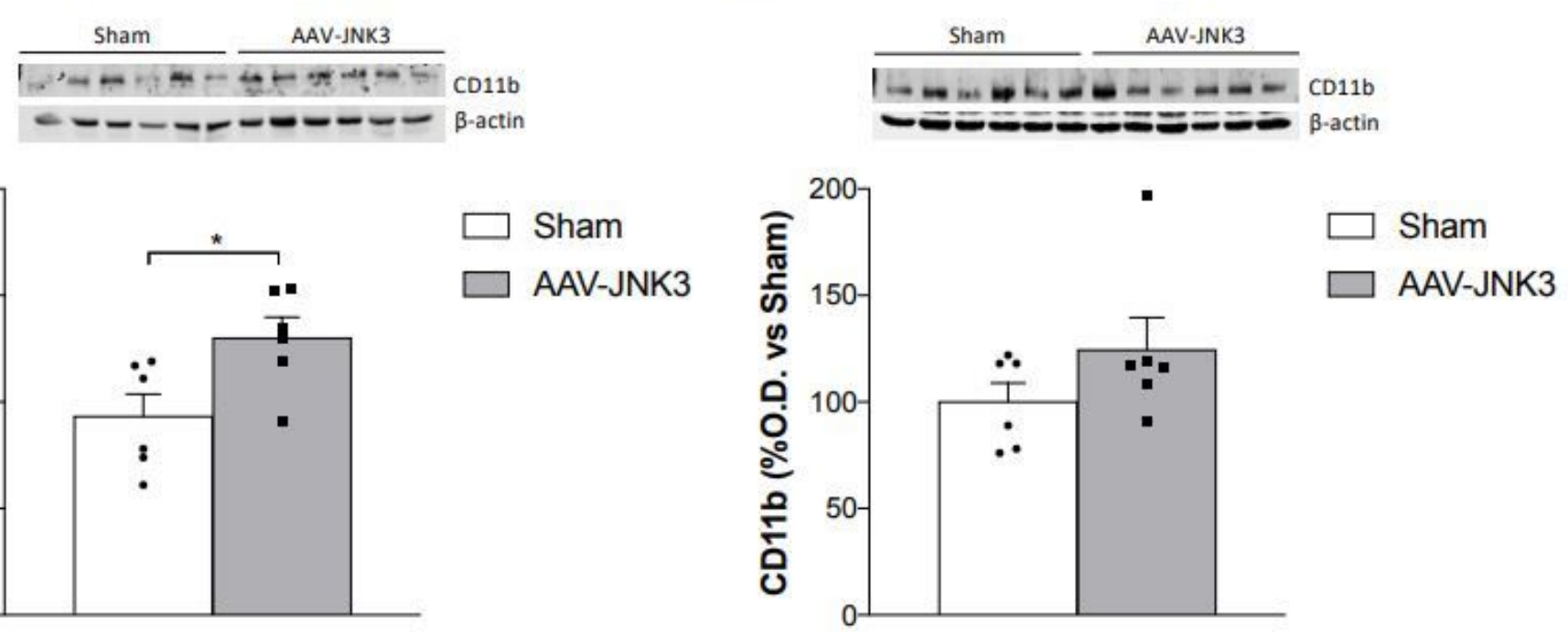

\section{Figure 4}

Effect of JNK3 overexpression on microgliosis. a) Iba1 expression in Sham and AAV-JNK3 injected mice and magnification images of medial EC, lateral EC and Hp. Scale bar: $100 \mu \mathrm{M}$. b) CD11b protein levels in the EC (Student's $t$ test, $t=2.619,{ }^{*} p<0.05 ; n=6$ ). c) CD11b protein levels in the Hp (Student's $t$ test, $t=1.397$, $p>0.05 ; n=6$ ). Results are shown as mean \pm SEM. In panels $b$ and $c$ figures show optical density (O.D.) values percentage and an illustrative image of the blotting. EC: entorhinal cortex; Hp: hippocampus; O.D.: optical density. 


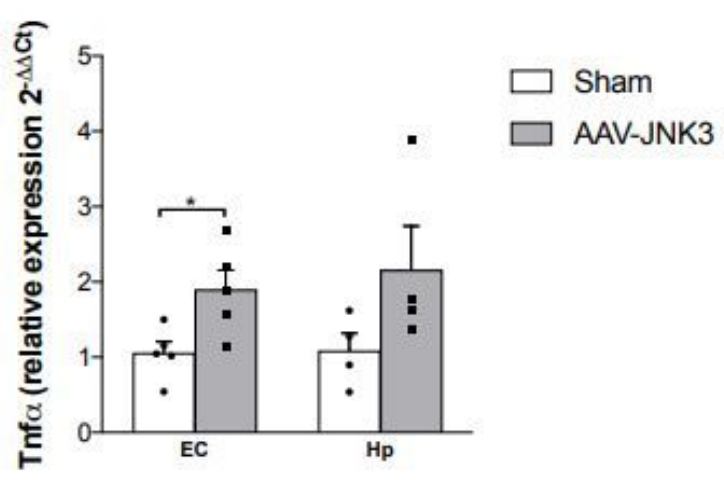

b

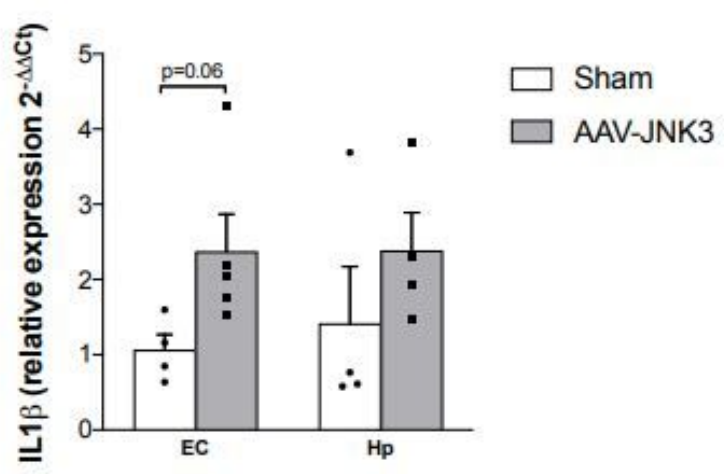

C

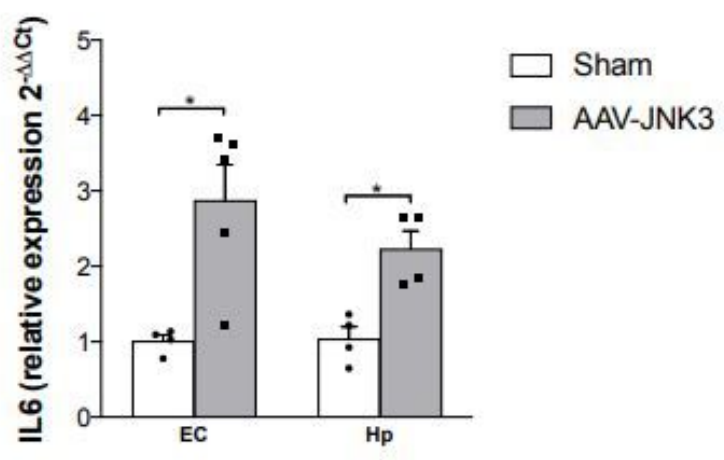

\section{Figure 5}

Effect of JNK3 overexpression on neuroinflammation. a) TNFa mRNA relative expression in the EC (Student's t test, $t=2.782,{ }^{*} p<0.05 ; n=5$ ) and Hp (Student's t test, $\left.t=1.703, p>0.05 ; n=5\right)$. b) IL1 $\beta$ mRNA relative expression in the $\mathrm{EC}$ (Student's $t$ test, $t=2.207, p=0.06 ; n=5$ ) and Hp (Student's t test, $t=1.065$, $p>0.05 ; n=5)$. c) IL6 mRNA relative expression in the EC (Student's t test, $\left.t=3.445,{ }^{*} p<0.05 ; n=5\right)$ and Hp 
(Student's $t$ test, $t=4.123, p>0.05 ; n=5)$. Results are shown as mean $\pm S E M$ and expressed as $2^{-\Delta \Delta C t}$. EC: entorhinal cortex; Hp: hippocampus; TNFa: tumor necrosis factor a; IL1ß: interleukin 1 $\beta$; IL6: interleukin 6.

a

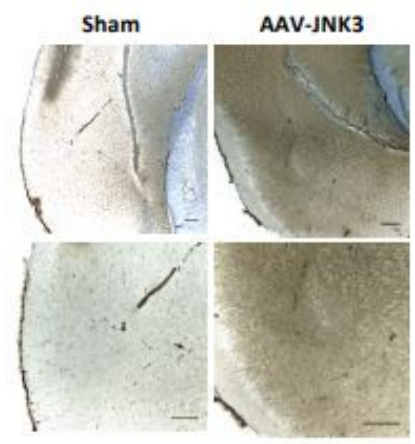

C

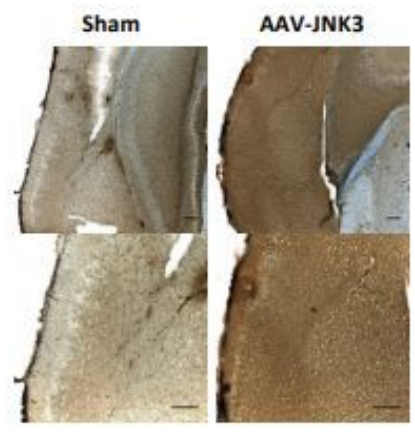

e

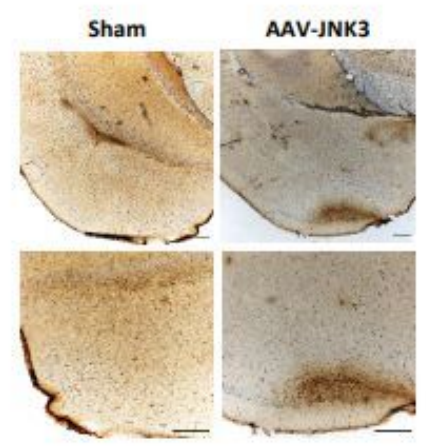

g

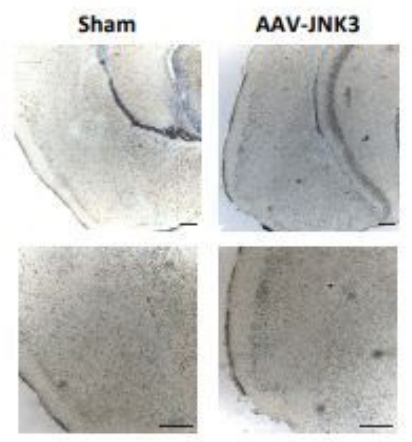

b

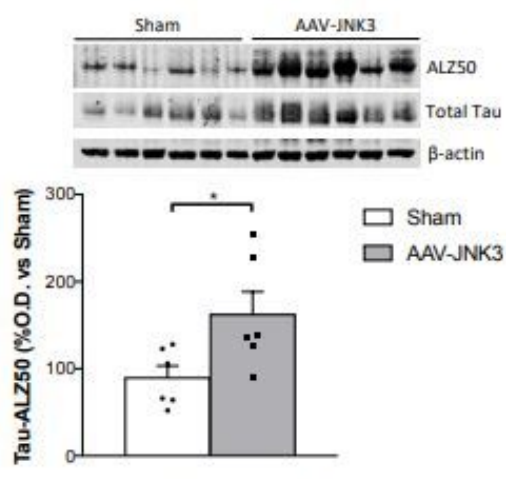

d
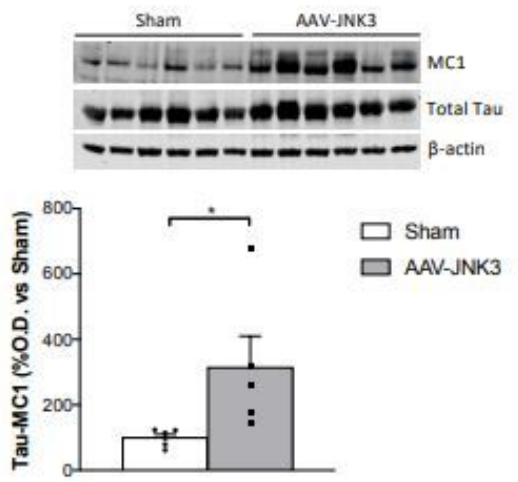

f
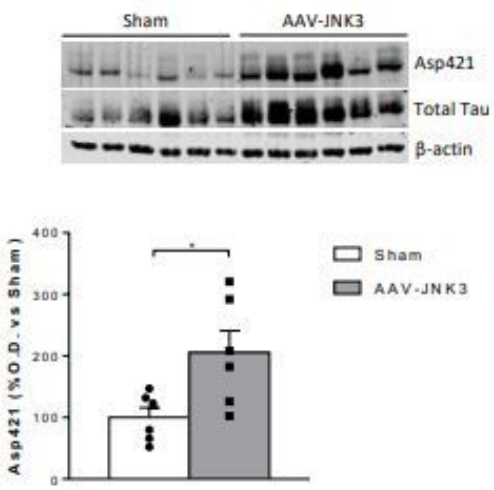

h
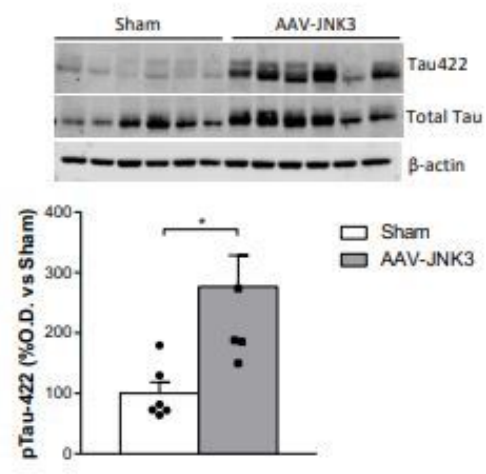

Figure 6 
Effect of JNK3 overexpression on Tau in the EC. a) Tau ALZ50 expression in Sham and AAV-JNK3 injected (upper panels) mice and magnification images (lower panels) of EC. Scale bar: $200 \mu \mathrm{M}$. b) Tau ALZ50 protein presence in EC (Student's $t$ test, $\left.t=2.459,{ }^{*} p<0.05 ; n=6\right)$. c) Tau MC1 expression in Sham and AAV-JNK3 injected mice (upper panels) and magnification images (lower panels) of EC. Scale bar: $200 \mu \mathrm{M}$. d) Tau MC1 protein presence in EC (Student's t test, $t=2.458,{ }^{*} p<0.05 ; n=6$ ). e) Asp421 truncated Tau expression in Sham and AAV-JNK3 injected mice (upper panels) and magnification images (lower panels) of EC. Scale bar: $200 \mu \mathrm{M}$. f) Asp421 truncated Tau protein presence in EC (Student's t test, $\left.t=2.694,{ }^{*} p<0.05 ; n=6\right)$. g) pTau Ser 422 expression in Sham and AAV-JNK3 injected mice (upper panels) and magnification images (lower panels) of EC. Scale bar: $200 \mu \mathrm{M}$. h) pTau Ser 422 presence in EC (Student's $t$ test, $t=3.211,{ }^{*} p<0.05 ; n=6$ ). Results are shown as mean $\pm S E M$. In panels $b$ and $d$ figures show optical density (O.D.) values percentage and a illustrative image of the blotting. 
a

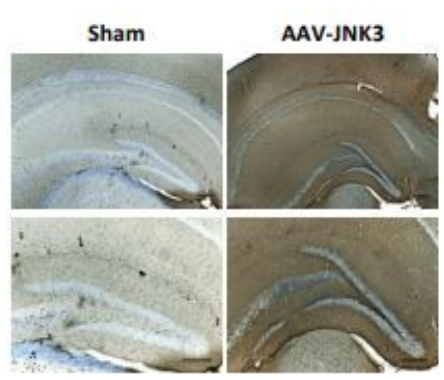

C

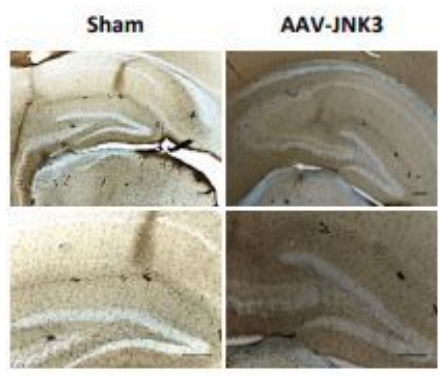

e

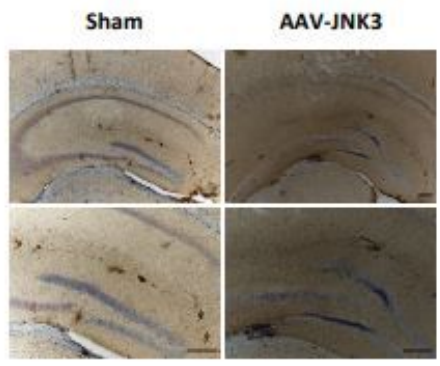

g

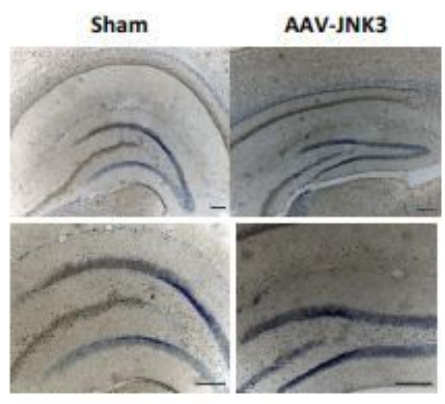

b

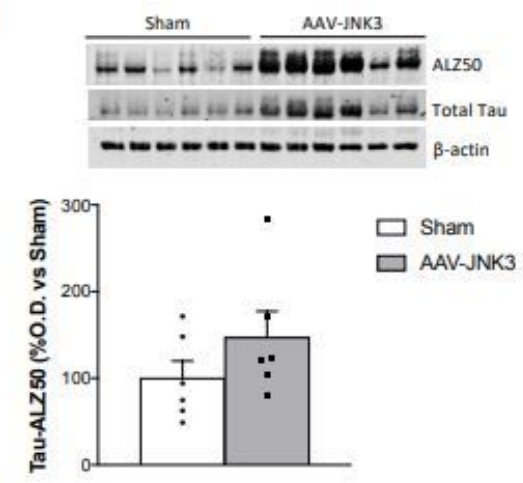

d

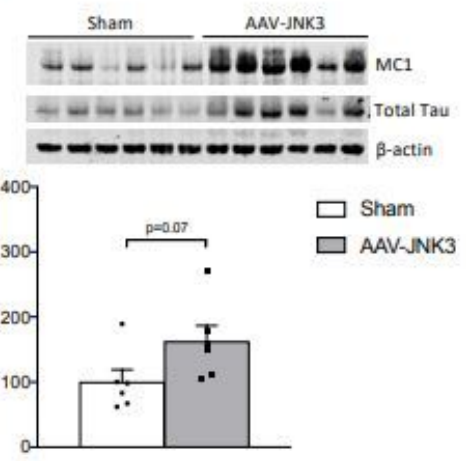

f
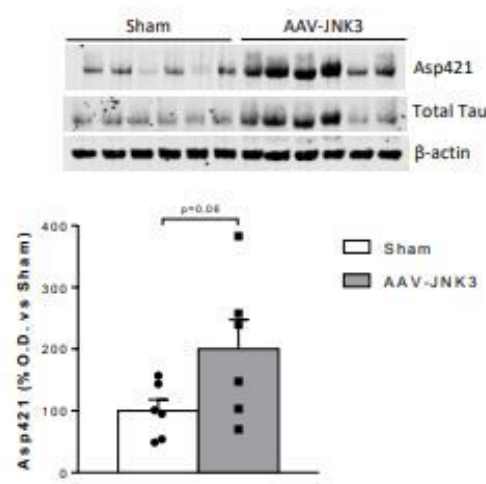

h

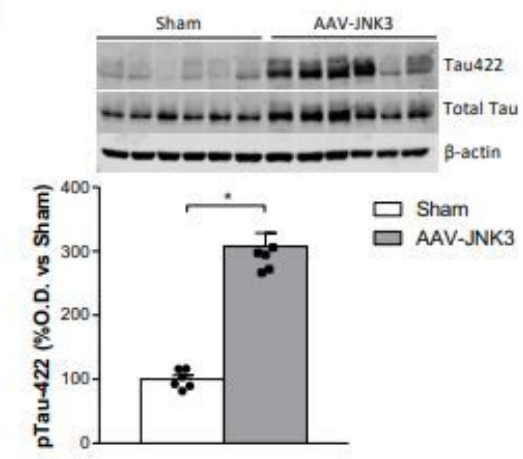

\section{Figure 7}

Effect of JNK3 overexpression on Tau in the Hp. a) Tau ALZ50 expression in Sham and AAV-JNK3 injected (upper panels) mice and magnification images (lower panels) of Hp. Scale bar: $200 \mu \mathrm{M}$. b) Tau ALZ50 protein presence in the Hp (Student's t test, $t=1.310, p>0.05 ; n=6)$. c) Tau MC1 expression in Sham and AAV-JNK3 injected mice (upper panels) and magnification images (lower panels) of Hp. Scale bar: $200 \mu$ M. d) Tau MC1 protein presence in the Hp (Student's t test, $t=2.011, p=0.07 ; n=6)$. e) Asp421 
truncated Tau expression in Sham and AAV-JNK3 injected mice (upper panels) and magnification images (lower panels) of Hp. Scale bar: $200 \mu \mathrm{M}$. f) Asp421 truncated Tau protein presence in the Hp (Student's t test, $\mathrm{t}=1.977,{ }^{\star} \mathrm{p}=0.07 ; \mathrm{n}=6$ ). g) pTau Ser 422 expression in Sham and AAV-JNK3 injected mice (upper panels) and magnification images (lower panels) of Hp. Scale bar: $200 \mu \mathrm{M}$. h) pTau Ser 422 presence in the $\mathrm{Hp}$ (Student's $t$ test, $t=9.460,{ }^{*} p<0.05 ; n=6$ ). Results are shown as mean $\pm S E M$. In panels $b, d$ and $f$ figures show optical density (O.D.) values percentage and an illustrative image of the blotting.

\section{Supplementary Files}

This is a list of supplementary files associated with this preprint. Click to download.

- SupplementaryFigure1.pdf 